\title{
SCOPE Climate: a 142-year daily high-resolution ensemble meteorological reconstruction dataset over France
}

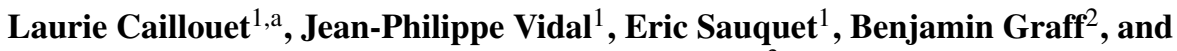 \\ Jean-Michel Soubeyroux ${ }^{3}$ \\ ${ }^{1}$ Irstea, UR RiverLy, Centre de Lyon-Villeurbanne, 5 rue de la Doua CS 20244, 69625 Villeurbanne, France \\ ${ }^{2}$ Compagnie Nationale du Rhône (CNR), 2 rue André Bonin, 69004 Lyon, France \\ ${ }^{3}$ Météo-France, Direction de la Climatologie et des Services Climatiques, 42 avenue Coriolis, \\ 31057 Toulouse Cedex 1, France \\ anow at: INRS, Centre Eau Terre Environnement, 490 rue de la Couronne, Québec (Québec) G1K 9A9, Canada
}

Correspondence: Laurie Caillouet (laurie.caillouet@gmail.com)

Received: 10 July 2018 - Discussion started: 2 August 2018

Revised: 30 December 2018 - Accepted: 29 January 2019 - Published: 21 February 2019

\begin{abstract}
SCOPE Climate (Spatially COherent Probabilistic Extended Climate dataset) is a 25-member ensemble of 142-year daily high-resolution reconstructions of precipitation, temperature, and Penman-Monteith reference evapotranspiration over France, from 1 January 1871 to 29 December 2012. SCOPE Climate provides an ensemble of 25 spatially coherent gridded multivariate time series. It is derived from the statistical downscaling of the Twentieth Century Reanalysis (20CR) by the SCOPE method, which is based on the analogue approach. SCOPE Climate performs well in comparison to both dependent and independent data for precipitation and temperature. The ensemble aspect corresponds to the uncertainty related to the SCOPE method. SCOPE Climate is the first century-long gridded high-resolution homogeneous dataset available over France and thus has paved the way for improving knowledge on specific past meteorological events or for improving knowledge on climate variability, since the end of the 19th century. This dataset has also been designed as a forcing dataset for longterm hydrological applications and studies of the hydrological consequences of climate variability over France. SCOPE Climate is freely available for any non-commercial use and can be downloaded as NetCDF files from https://doi.org/10.5281/zenodo.1299760 for precipitation, https://doi.org/10.5281/zenodo.1299712 for temperature, and https://doi.org/10.5281/zenodo.1251843 for reference evapotranspiration.
\end{abstract}

Historical surface meteorological observations like precipitation and temperature are more and more scarce and sparse when going back in time to before the 1950s. Even in a datarich country like France, the number of available stations in databases is reduced to only a few in the early 1870 s. Data rescue efforts are ongoing (Jourdain et al., 2015) but the present state of databases prevents us performing centurylong analyses of climate variability and extremes over large regions in a both spatially and temporally homogeneous way. In some other countries with an observation network that started earlier with a higher density like the UK, long-term gridded datasets of daily rainfall have been derived based on the interpolation between stations from 1890 onwards (Keller et al., 2015). Similarly, daily gridded estimates of potential evapotranspiration have recently been derived from the network of mean monthly temperature observations in the UK from 1891 onwards (Tanguy et al., 2018).

Two global reanalyses spanning the entire 20th century have recently been released: the Twentieth Century Reanalysis (20CR, Compo et al., 2011) and the European Reanalysis of the Twentieth Century (ERA-20C, Poli et al., 2016). They provide the opportunity to reconstruct long-term local- 
scale meteorological data through downscaling techniques, avoiding the use of non-homogeneous ground observation networks. Statistical downscaling methods may be used to derive daily local-scale near-surface meteorological variables from synoptic-scale atmospheric variables provided by such global extended reanalyses. 20CR has already been downscaled for specific regions in France (e.g. Kuentz et al., 2015) or for the entire country (Minvielle et al., 2015; Dayon et al., 2015; Bonnet et al., 2017) but without a locally optimized method and/or in a deterministic way, thus preventing any analyses from focusing on the detailed local outputs and/or the downscaling uncertainty.

Caillouet et al. $(2016,2017)$ proposed a statistical downscaling of 20CR over the period 1871-2012 with an ensemble method locally optimized over France - based on an analogue resampling of the existing 50-year-long Safran near-surface reanalysis (Vidal et al., 2010) - in order to improve the knowledge on past hydrometeorological conditions and climate variability, since the end of the 19th century in France. SCOPE Climate (Spatially COherent Probabilistic Extended Climate dataset), the resulting dataset, is a daily high-resolution ensemble reconstruction of precipitation, temperature and Penman-Monteith reference evapotranspiration fields in France from 1 January 1871 to 29 December 2012. Available on a $8 \mathrm{~km}$ grid, SCOPE Climate has the appropriate space and time resolutions for various hydrological applications, such as the study of drought events, large-scale floods or streamflow variability over the 20th century; see Caillouet et al. (2017) for an application on reconstructing historical low-flow events. This paper proposes making SCOPE Climate accessible to the research community.

The most generic methodological choices have been made in the creation of SCOPE Climate to promote the widest possible use of the dataset, e.g. by not favouring precipitation over temperature or low extremes over high ones. The length (142 years), the spatial availability (whole of France) as well as the ensemble aspect ( 25 members) will enable various spatio-temporal analyses - such analyses may take account of the uncertainty in the statistical downscaling step - to enhance the knowledge of past meteorology and climate, and their hydrological impacts. SCOPE Climate moreover provides spatially consistent multivariate gridded time series for each ensemble member, which make it suitable for studies requiring both inter-variable and spatial consistency, e.g. catchment-scale hydrology.

This paper presents the SCOPE Climate dataset, first by introducing the methodological framework developed to derive it in Sect. 2. Characteristics of SCOPE Climate are then detailed in Sect. 3 through examples and validation results. Section describes how to access the dataset, and Sect. 5 considers some of its limitations.

\section{Statistical downscaling of $20 \mathrm{CR}$ with the SCOPE method}

\subsection{Data}

\subsubsection{Source for local predictands: Safran}

Safran is the French near-surface reanalysis available on the hourly timescale and $8 \mathrm{~km}$ spatial resolution, from $1 \mathrm{Au}-$ gust 1958 onwards (Vidal et al., 2010). Safran was derived based on an optimal interpolation between all surface observations available in the Météo-France database and a first guess from the ERA-40 reanalysis (Uppala et al., 2005) until 2002 and from ECMWF operational analyses afterwards for 608 climatically homogeneous zones in France (QuintanaSeguí et al., 2008). Daily reference evapotranspiration was computed based on the hourly Penman-Monteith formula (Allen et al., 1998). Vidal et al. (2010) showed that the Safran errors in precipitation are relatively low and constant over the 1958-2008 period, while Safran errors in temperature are decreasing with an increasing number of assimilated surface observations.

Local predictands used to derive SCOPE Climate are gridded daily precipitation, temperature, and reference evapotranspiration over the period 1 August 1958 to 31 July 2008. More recent Safran data can therefore be used for a completely independent comparison.

\subsubsection{Source for atmospheric predictors: $20 \mathrm{CR}$}

The Twentieth Century Reanalysis (20CR) is a large-scale reanalysis spanning the entire 20th century and developed by the National Oceanic and Atmospheric Administration (NOAA) (Compo et al., 2011). 20CR V2 chosen here only uses 6-hourly surface level pressure (SLP) observations from the International Surface Pressure Databank (ISPD v2.2, Compo et al., 2010) in the ensemble Kalman filter assimilation process and the monthly sea surface temperature (SST) and sea-ice concentration fields from the Hadley Centre global sea ice and sea surface temperature (HadISST, Rayner et al., 2003) as boundary conditions. This choice has been made to avoid inhomogeneities due to the assimilation of observations from different systems.

Six atmospheric predictors are considered in the downscaling process used to derive SCOPE Climate: temperatures at 925 and $600 \mathrm{hPa}$, geopotential heights at 1000 and $500 \mathrm{hPa}$, vertical velocity at $850 \mathrm{hPa}$, precipitable water content, relative humidity at $850 \mathrm{hPa}$ - all from the 6-hourly analysis - and large-scale $2 \mathrm{~m}$ temperature (T2m) from the 6-hourly forecast.

20CR predictors are available at $2.0^{\circ}$ spatial resolution and 6-hourly temporal resolution from 1 January 1871 to 31 December 2012. Five predictors - temperature, geopotential height, vertical velocity, precipitable water content, and relative humidity - have been spatially interpolated with a bilinear interpolation on a $2.5^{\circ}$ grid for input of the downscal- 
ing method. The ensemble mean of the 56-member ensemble of 20CR was considered for building SCOPE Climate (see Sect. 5).

\subsubsection{Source for oceanic predictor: ERSST}

The NOAA Extended Reanalysis Sea Surface Temperature (ERSST) version $3 \mathrm{~b}$ is a global sea surface temperature (SST) reanalysis and has been available at a $2.0^{\circ}$ spatial resolution and a monthly temporal resolution since 1 January 1854 (Smith and Reynolds, 2003; Smith et al., 2008). Like 20CR, this version does not use satellite data to avoid inhomogeneities. Monthly values of SST over the optimised grid cell south of Brittany $\left(4^{\circ} \mathrm{W}, 46^{\circ} \mathrm{N}\right)$ over the period 1871-2012 were extracted and interpolated with splines to the daily timescale required by the downscaling process (see Appendix B in Caillouet et al., 2017) and constitutes the seventh large-scale predictor of the SCOPE method.

\subsection{The SCOPE statistical downscaling method}

The Spatially COherent Probabilistic Extension method (SCOPE, Caillouet et al., 2017) is the statistical method used to downscale 20CR and derive the SCOPE Climate dataset. SCOPE is an extension of the Statistical ANalogue Downscaling method for HYdrology (SANDHY, Ben Daoud et al., 2011, 2016; Radanovics et al., 2013). It can be divided in four steps that have been briefly described in the Appendix B of Caillouet et al. (2017) and that are detailed in the paragraphs below:

- applying the SANDHY method (Sect. 2.2.1),

- subselecting SANDHY analogues to reconstruct both precipitation and temperature (Sect. 2.2.2),

- correcting for precipitation bias (Sect. 2.2.3),

- ensuring spatial coherence (Sect. 2.2.4).

\subsubsection{Step 1: Applying the SANDHY method}

The SANDHY method is an ensemble statistical downscaling method following an analogue approach. It is based on the idea introduced by Lorenz (1969) that similar atmospheric situations lead to similar local effects. The analogue approach uses two concurrent datasets, a large-scale reanalysis containing predictors and a local-scale meteorological dataset containing predictands. SANDHY thus uses two periods: a target period, over which reconstruction take place, and an archive period, from which analogue meteorological situations are picked up to reconstruct the target period. The two datasets (here 20CR and Safran) have to be available throughout the archive period, in which the predictorpredictand relationship is set up. In this reconstruction set-up, only the large-scale reanalysis (20CR) must be available over the entire target period. For a date in the target period, largescale predictors are compared to those of all dates over the archive. Dates from the archive period with the most similar predictors are then chosen as analogues. Local-scale predictand from the selected analogue dates are taken as an ensemble of plausible predictand values for the target date.

As SANDHY was initially aimed at quantitative precipitation forecasting, the predictand is daily precipitation. The predictors are used in four analogy levels, i.e. four consecutive subsampling steps, optimized by Ben Daoud et al. (2011, 2016). The first level selects $N$ analogue days on temperature at 925 and $600 \mathrm{hPa}$ with the exclusion of a 9-day window centred on the target date. $N$ is taken as 100 times the number of years in the archive period. The second level selects 170 analogues on geopotential heights of 500 and $1000 \mathrm{hPa}$. The third level selects 70 analogues thanks to an analogy on vertical velocity at $850 \mathrm{hPa}$ and the final level selects 25 analogues on humidity, which is considered as the product of the precipitable water content and the relative humidity at $850 \mathrm{hPa}$.

The similarity criterion used for the analogy levels on temperature, vertical velocity, and humidity is the Euclidean distance, with equal weights when different pressure levels are used. The analogy on geopotential height is measured through the shape similarity between fields with the Teweles and Wobus (1954) criterion. The predictor domain (spatial domain where the analogy is sought) depends on the Safran zone considered. The spatial domain for the first, third, and fourth analogy levels is the closest large-scale grid point to each zone. For the analogy level on geopotential, this domain had been originally optimized by Radanovics et al. (2013) over the 1 August 1982-31 July 2002 period on the 608 climatically homogeneous Safran zones covering France using predictors from ERA-40 (Uppala et al., 2005). SCOPE Climate was produced by re-optimizing the spatial domain following the Radanovics et al. (2013) method, but with 20CR predictors. Five near-optimal domains are obtained for each zone in France using an algorithm of growing rectangular domains. The performance criterion for this optimization was the continuous ranked probability score (CRPS, Brown, 1974; Matheson and Winkler, 1976), widely used for probabilistic verification forecast. Domains found from neighbouring zones were also considered if they provide a better performance.

The synthetic diagram in Fig. 1 summarizes the different steps described above. 20CR variables are used as predictors (see Sect. 2.1.2), whereas Safran precipitation is selected as a predictand (see Sect. 2.1.1). The archive period over which the predictors-predictand relationship is set up is 1 August 1958 to 31 July 2008. The target period considered is the whole period spanned by $20 \mathrm{CR}$ V2 data, i.e. 1 January 1871 to 31 December 2012. The different downscaling steps are applied 5 times using one of the near-optimal analogy domain for geopotential at each run. The application of SANDHY with these settings provides an ensemble of 125 analogue dates for each date in the target period, indepen- 


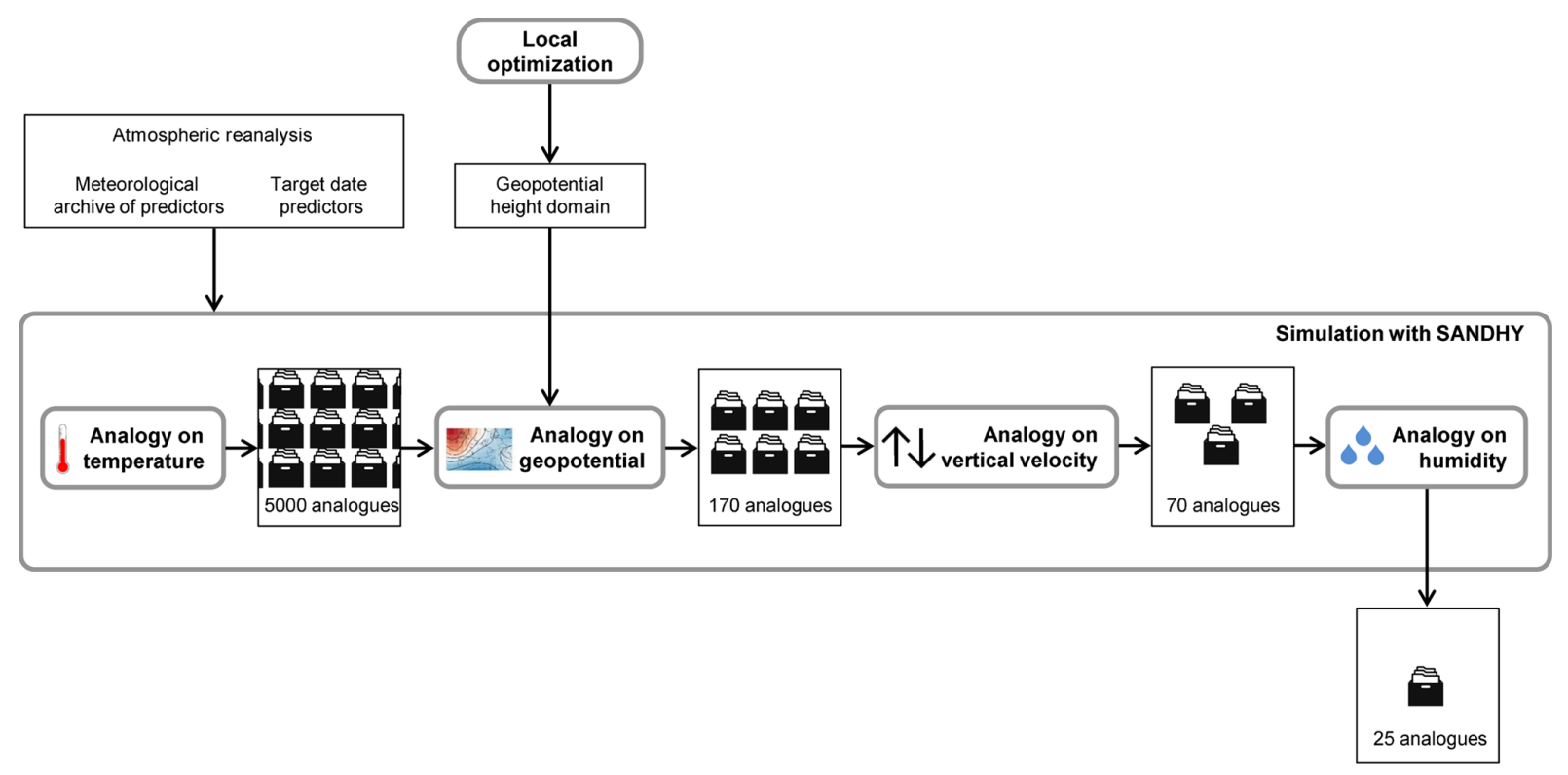

Figure 1. Synthetic diagram showing the sequence of analogy steps in the SANDHY method to reconstruct precipitation and temperature over a given climatically homogeneous zone and for a specific target date.

dently for the 608 climatically homogeneous zones covering France. Applying SANDHY to each zone leads to no spatial consistency between zones, the latter being added with the method presented in Sect. 2.2.4.

Analogues dates included in the period 1 August 1958 to 31 July 2008 are then converted to meteorological variables by resampling Safran reanalysis data. The analogues obtained from SANDHY are not only used for precipitation, but also for temperature and reference evapotranspiration.

\subsubsection{Step 2: Subselecting SANDHY analogues}

An overestimation of precipitation in spring and an underestimation of precipitation in autumn was found in SANDHY outputs for zones with high seasonal asymmetry (e.g., Mediterranean areas). Moreover, winter and summer temperatures were respectively over- and underestimated (Caillouet et al., 2016). This last result was not unexpected since SANDHY predictors were chosen for their strong relation to precipitation and not to temperature. To reduce these biases while keeping unchanged the structure of the SANDHY method, two analogy levels have been applied to the 125 analogues dates resulting from the application of SANDHY.

This method is called stepwise subselection and was described by Caillouet et al. (2016). The first additional analogy level selects 80 analogues out of 125 based on the similarity of SST values. The second level selects 25 analogues based on the similarity of $\mathrm{T} 2 \mathrm{~m}$ values. The number of analogues at each level was optimized by Caillouet et al. (2016). The similarity criterion for both levels is the Euclidean distance. For the sake of consistency over France and parsimony of parameters, a single grid point common to all climatically homo- geneous zones in France is used for computing the analogy on SST (optimised at location $4^{\circ} \mathrm{W}, 46^{\circ} \mathrm{N}$ ). The grid point for computing the $\mathrm{T} 2 \mathrm{~m}$ analogy is chosen as the land grid point closest to each climatically homogeneous zone, following the approach used for levels 1, 3, and 4 in the standard SANDHY method. A detailed validation of results from the chain SANDHY + stepwise (also called SANDHY-SUB) for temperature and precipitation over France was performed by Caillouet et al. (2016).

\subsubsection{Step 3: Correcting for precipitation bias}

A third step consists of a bias correction of SANDHY-SUB precipitation. Indeed, the median of annual precipitation between Safran and the reconstructed precipitation showed a dry bias of around $10 \%$ (see Caillouet et al., 2016). Instead of applying common bias correction techniques, a correction approach similar to the one adopted by Sippel et al. (2016) has been considered here, keeping a maximum inter-variable coherence that is inherent to analogue methods.

For each target date between 1871 and 2012, the $N$ analogues giving the lowest precipitation, including zeros, are removed. $N$ analogues are then randomly resampled from the $(25-N)$ left to keep a 25 -member sample size. $N$ is independently defined for each of the 608 zones in France. It is defined so that the bias with respect to Safran data (over the archive period) is minimized and has values ranging from 0 to 3 across France. By construction, this number increases with precipitation underestimation. All variables - precipitation, but also temperature and evapotranspiration - that correspond to the removed $N$ analogue dates are discarded, therefore preserving the inter-variable consistency. Impor- 
tantly, this resampling-based correction of precipitation does not affect the temperature bias and interannual correlation described in Caillouet et al. (2016). This technique allows one to retrieve a near-zero bias in mean interannual precipitation over France.

\subsubsection{Step 4: Ensuring spatial coherence}

The last step in building SCOPE Climate is to add some spatial coherence to ensemble member fields. Indeed, in order to build gridded time series, analogue dates across zones must be combined. The resulting lack of spatial coherence when using a random combination could be heavily detrimental to the use of SCOPE Climate for applications requiring spatial coherence, like hydrological studies. This issue is addressed here by applying the Schaake Shuffle procedure, initially developed to reconstruct space-time variability in forecast meteorological fields (Clark et al., 2004). In this approach, the ensemble members are reordered so that their rank correlations across both space and variables match the ones from a randomly picked sample of observed multivariate fields. In the present application, rank correlations are considered across the 608 climatically homogeneous zones and across the three variables (precipitation, temperature, and reference evapotranspiration). Observed fields are taken from the Safran reanalysis.

For each target date, 25 dates are randomly selected within a 120-day window around the corresponding day of the year and from the period 1 August 1958 to 31 July 2008, a period consistent with the archive period for analogue dates in the SANDHY downscaling step. Observed rank correlations are derived from the Safran multivariate meteorological fields for this ensemble of 25 dates and applied to the reconstructed ensemble, thus ensuring the spatial coherence of any single ensemble member. Even if the reordering is done independently for each variable, the inter-variable consistency is ensured by the use of the same date for computing rank correlations. The inter-variable consistency is therefore as good as in Safran, modulo the impact of ties (see Clark et al., 2004). As the set of analogues remains the same for each day and is only shuffled across ensemble members, local characteristics such as median ensemble bias do not change.

Figure 2 provides a summary of the different steps of the SCOPE method, described above. It consists first of applying the SANDHY-SUB method developed by Caillouet et al. (2016), which adapts the SANDHY statistical downscaling method to the additional temperature predictor. Then, a correction of seasonal precipitation biases is applied. Finally, spatially coherent reconstructions over France are achieved through an adaptation of the Schaake Shuffle method.

\section{The resulting dataset: SCOPE Climate}

SCOPE Climate is the gridded climate dataset derived from the downscaling of $20 \mathrm{CR}$ using the SCOPE method. It consists of an ensemble of 25 equally plausible individual members of multivariate gridded meteorological series. Each member gathers daily gridded times series of precipitation, temperature, and reference evapotranspiration for the period 1 January 1871 to 29 December 2012 on a $8 \mathrm{~km}$ grid over France. For a given date and a given member, values are coherent over space and across the three variables.

The sections below provide weather and climate examples from SCOPE Climate, followed by a validation against Safran. For some figures, specific members are selected to provide examples of gridded fields or individual time series. Still, considering all 25 members of SCOPE Climate is essential for any use of the dataset.

\subsection{Weather and climate examples from SCOPE Climate}

\subsubsection{Daily spatial features: 18-20 January 1910 precipitation and temperature over France}

January 1910 was a particularly wet month in France, especially in the Seine catchment. The combination of heavy rain during this month, saturated soils at the end of December 1909, frozen grounds and melting snow, led to widespread floods in the Seine catchment (Lang et al., 2013). The succession of several perturbations between 17 and 20 January resulted in above-average precipitation accumulation with more than $130 \mathrm{~mm}$ in the Morvan, usually corresponding to the amount of rain for the entire month of January ${ }^{1}$ (Schneider, 1997). The period 18 to 20 January, corresponding to the peak of the event, was chosen as the first reconstruction example. Precipitation totals over this 3-day period are partly responsible for the most studied 100-year flood of the Seine in Paris and its tributaries (Nouailhac-Pioch and Maillet, 1910; Marti and Lepelletier, 1997; Delserieys and Blanchard, 2014), but also for other important floods on the Rhine (Martin et al., 2011) or Rhône (Pardé, 1925) tributaries.

The top row of Fig. 3 shows the maps of 18, 19, and 20 January 1910 daily precipitation from available observations in the Météo-France database. It has to be noted that particular efforts toward data rescue have been employed for the Seine river basin, resulting in a high density of available observations. Daily precipitation amounts above $50 \mathrm{~mm}$ were recorded over several mountain ranges (Morvan, southern Vosges, Jura, and the northern French Alps), especially for the 18 and 19 January. The north-west of France (Brittany) and the south-west of France are also affected by high precipitation amounts, respectively on the 20 January and the 1819 January. The south-east of France and Corsica remained quite dry (except for one station in the mountain range of Corsica). However, several regions suffer from a lack of ob-

\footnotetext{
${ }^{1}$ http://www.meteofrance.fr/actualites/ 34465980-crue-de-la-seine-quelle-meteo-en-1910 (last access: 19 February 2018.)
} 


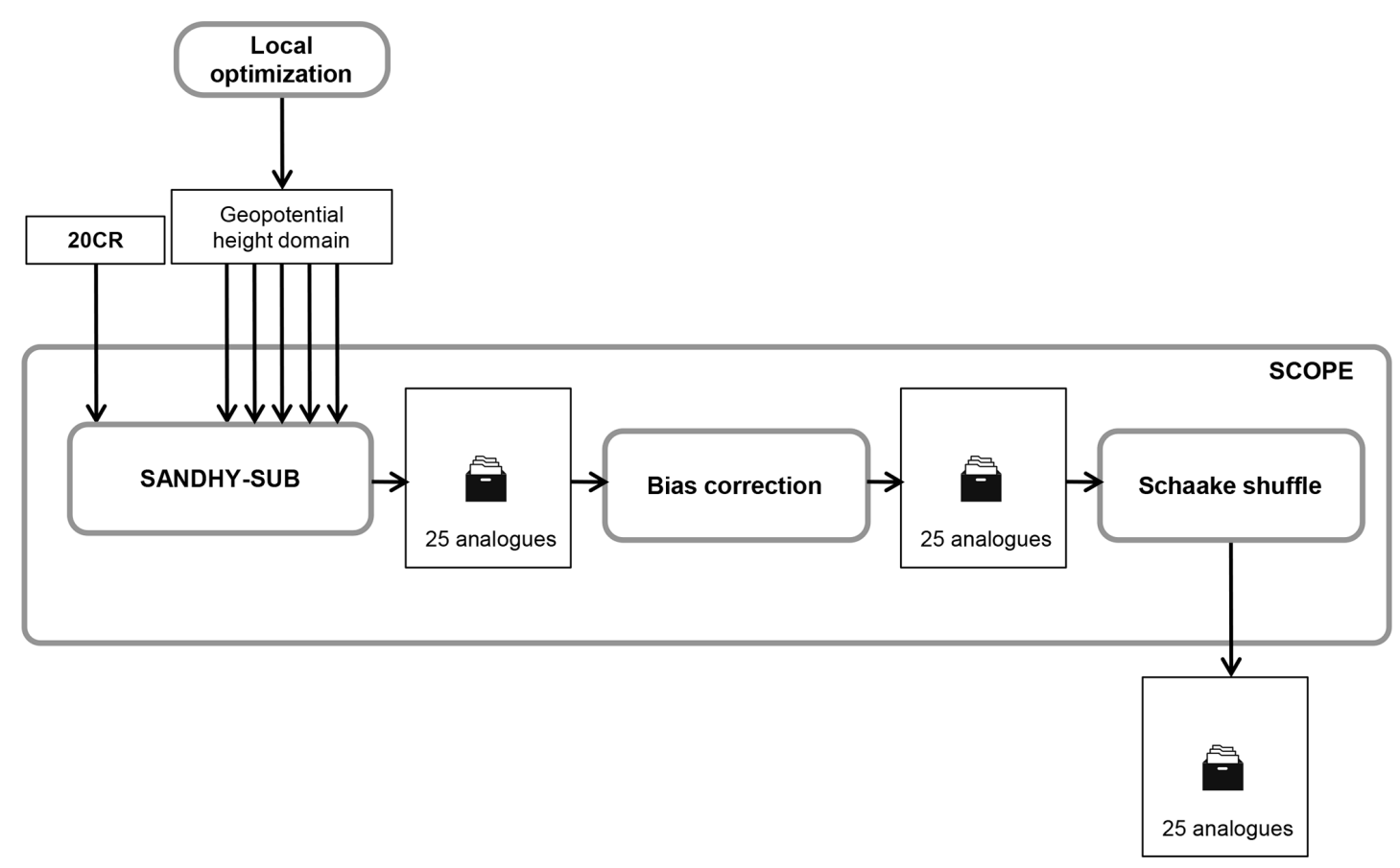

Figure 2. Synthetic diagram showing the sequence of steps for the SCOPE method and its use for SCOPE Climate reconstructions. Reproduced from Caillouet et al. (2016).

servations: Picardie (north), the main part of the Loire basin (centre), Jura mountain range (east), most of the Alps, and Provence (south-east).

Concurrent SCOPE Climate precipitation reconstructions are presented on rows $2-7$ of Fig. 3 with six randomly selected members. Some members provide high amounts of precipitation for almost the whole of France (on 18 January for member 5 and on 19 January for member 25) with an emphasis on mountain ranges (Vosges, Jura, and the French Alps). Some members provide high precipitation amounts on a diagonal from the north-east to the south-west (on 19 and 20 January for member 10 and on the 18 January for member 17). Others provide high precipitation for particular zones in France (Brittany for member 3 on 19 January, east for member 8 on the 8 January). Four members out of the six randomly selected members provide more than $100 \mathrm{~mm}$ of precipitation for the French Alps and Jura on a particular day (members 5, 10, 17, and 25), a zone without available precipitation observations but where important floods have been recorded (Boudou et al., 2016).

Figure 4 provides the maps of surface temperature for the 18 to 20 January 1910 from available observations (top) and the same six selected members of SCOPE Climate. Spatial patterns of reconstructed temperature are in good agreement with each other and with observations. Values are largely positive over the Seine catchment, in agreement with snowmelt records. This example demonstrates the ability of SCOPE Climate to fill in the spatial gaps of missing data and to provide a spatially coherent reconstruction of temperature.

\subsubsection{Temporal features: time series at Lyon-Bron Airport}

The evaluation of SCOPE Climate against independent data is possible using homogenized series provided by MétéoFrance (Moisselin et al., 2002; Moisselin and Schneider, 2002). These series were computed at a monthly time step using a statistical procedure detecting breaks and outliers in long time series of observations with sufficient quality. The 323 monthly precipitation series and 65 monthly time series of minimum and maximum temperature spanning the whole of the 20th century were retained for the evaluation. Monthly mean temperature time series were obtained by averaging minimum and maximum temperatures as done by Moisselin and Schneider (2002). The closest $8 \mathrm{~km}$ grid point to the observation station is selected for the comparison. It has to be noted that comparisons between gridded products like Safran or SCOPE Climate and station data should be taken with caution as corresponding variables may have different properties, e.g. due to spatial representativity and altitude.

The Lyon-Bron Airport station holds very long time series (since 1881 for precipitation and 1885 for temperature) already used in climate variability studies (see e.g. Thibert et al., 2013). Here the annual and seasonal evolution of precipitation are compared (Fig. 5), as well as temperature (Fig. 6) from (1) the homogenized series, (2) Safran data, and (3) the range of reconstructed series from SCOPE Climate.

Precipitation reconstructions from Fig. 5 show a very satisfactorily reconstructed interannual variability on the annual 

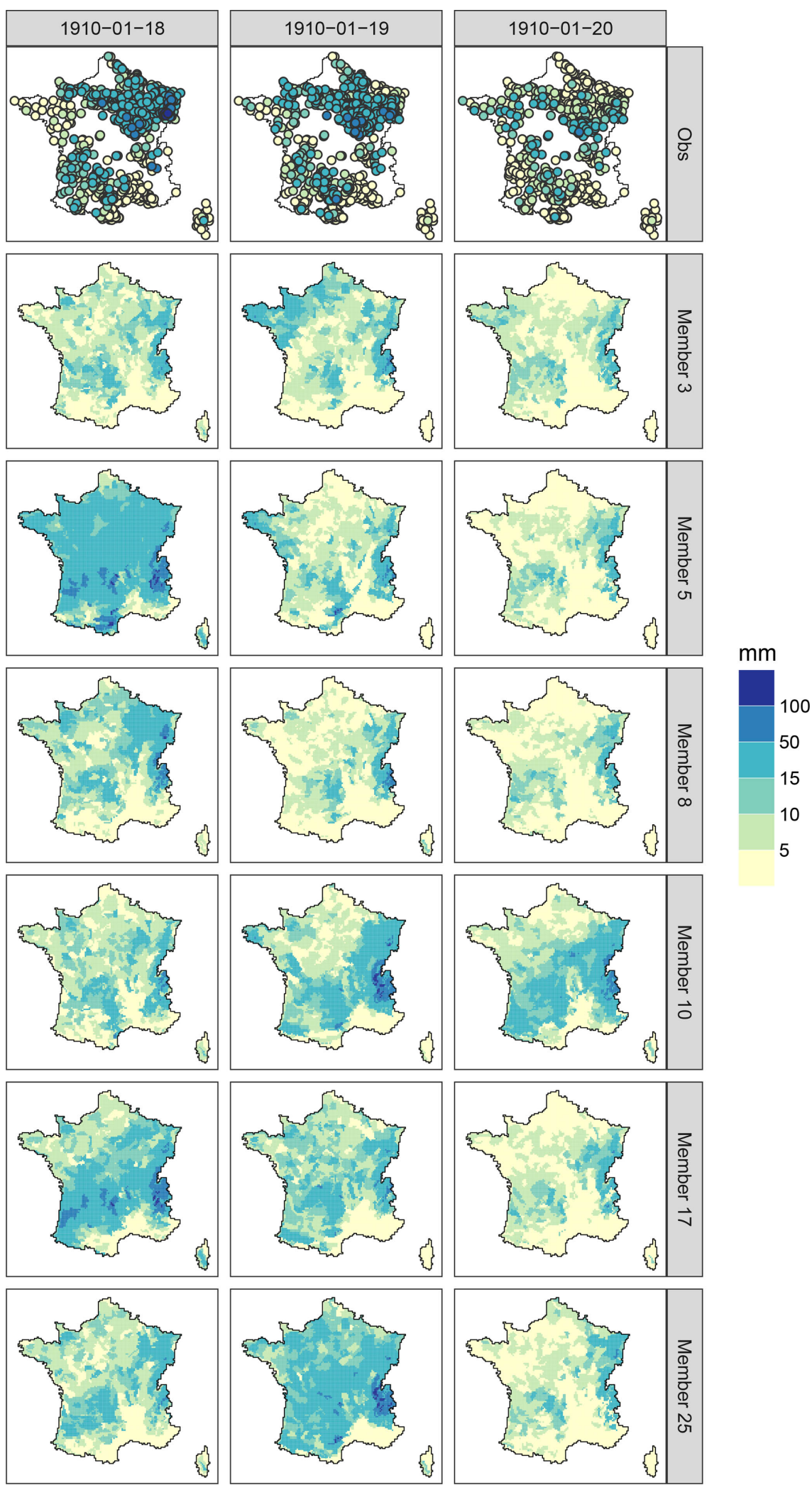

Figure 3.18 to 20 January 1910 precipitation. Top: observations currently available from the Météo-France database. Rows 2-7: six randomly selected members of SCOPE Climate. 

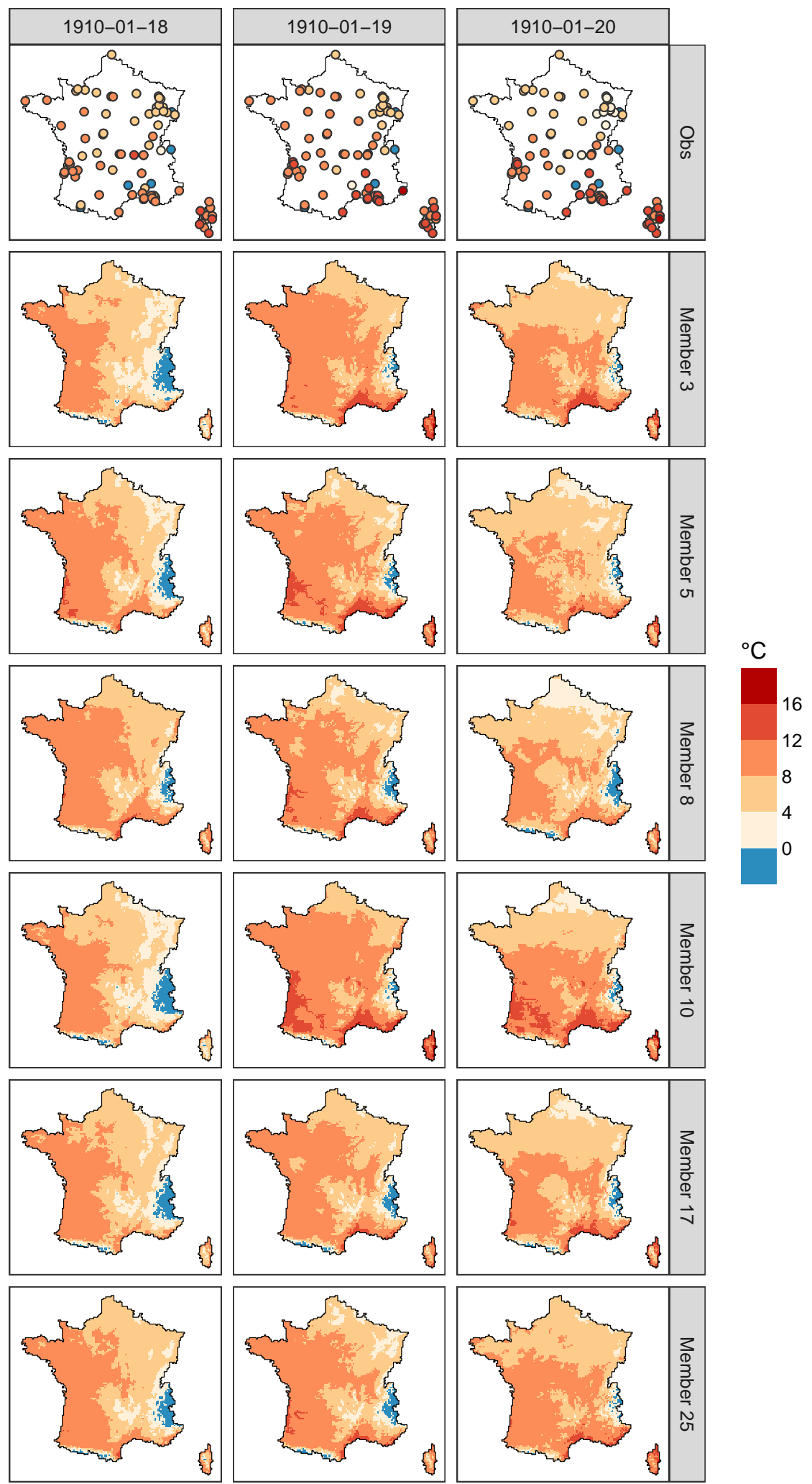

Figure 4. As for Fig. 3, but for mean temperature. 

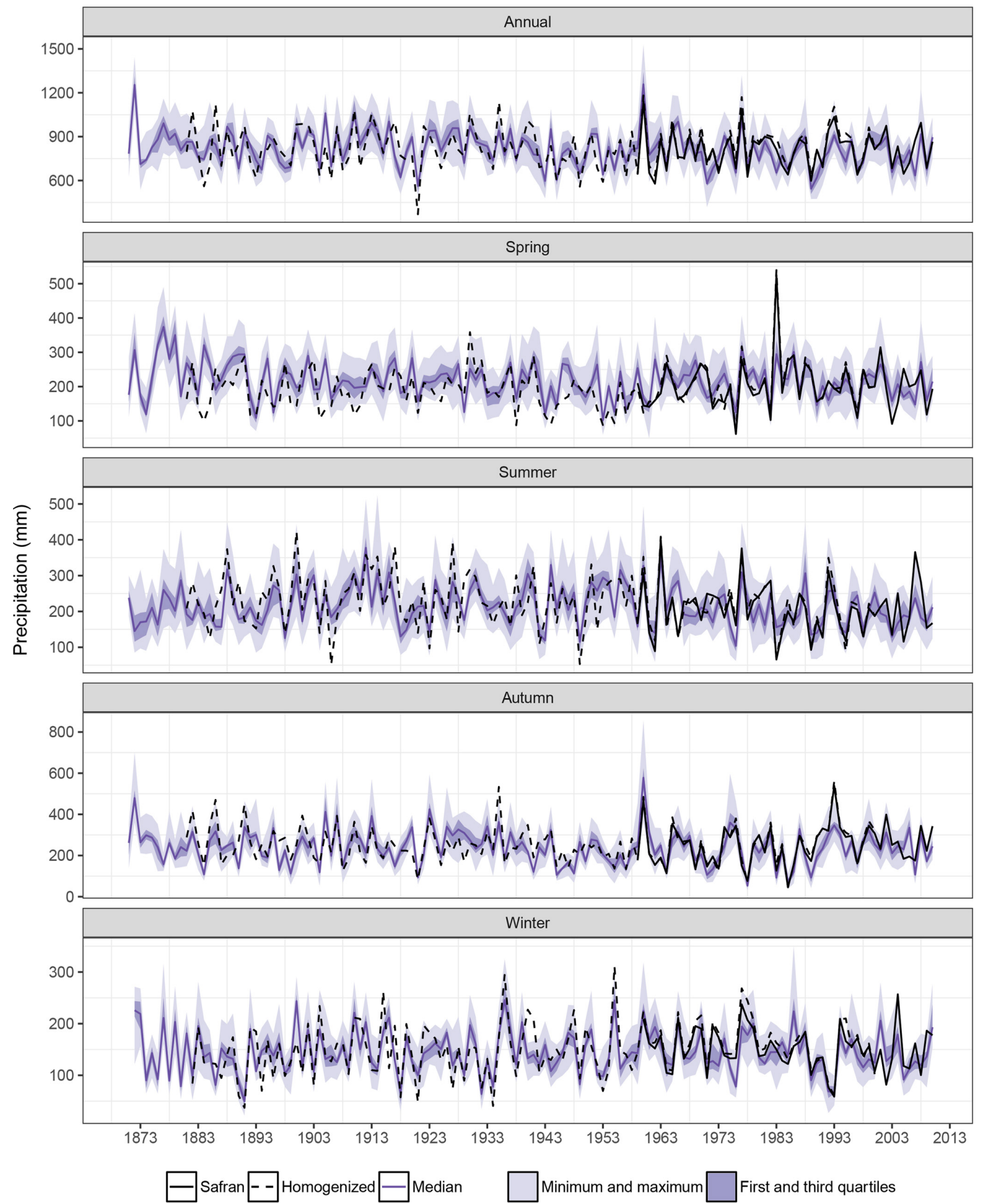

Figure 5. Lyon-Bron precipitation homogenized time series, corresponding Safran data, and reconstructed series from SCOPE Climate on the annual and seasonal timescales over the 1871-2012 time period. Light and dark purple areas define the range and the interquartile range, respectively, of values from SCOPE Climate members. Note the different scales for the $y$ axes.

and seasonal timescales. Except for some specific years, observations (from both homogenized series and Safran) stay inside the range of the 25 reconstructions. On the annual timescale, exceptional years - such as the 1921 dry year (Duband et al., 2004) or the 1960 wet year (Pardé, 1961) - are well captured by SCOPE Climate. The few years before 1897 show a lower reconstruction skill. SCOPE Climate shows a high annual precipitation in 1872 , for which no data are available. Nevertheless, Gautier et al. (2004) described one of the biggest floods in the Loire basin, in October 1872, and 

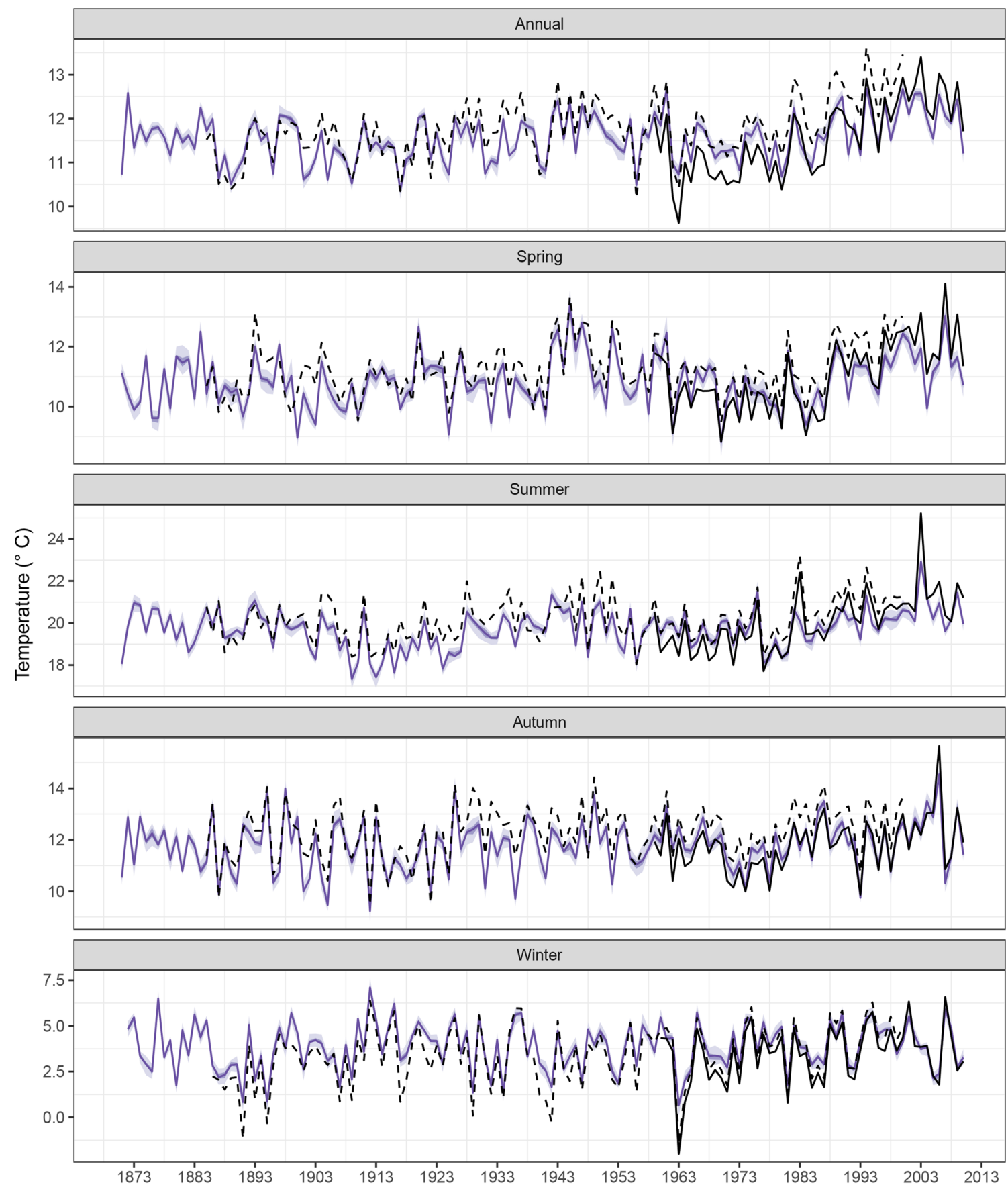

$\square$ Safran -- Homogenized $\square$ Median

$\square$ Minimum and maximum $\square$ First and third quartiles

Figure 6. As for Fig. 5, but for temperature.

heavy precipitation in Roanne and Macon, two towns close to Lyon. SCOPE Climate has difficulty simulating the extreme wet spring and dry summer of 1983 (Blanchet, 1984). Nevertheless, other extreme events like the wet winter of 1936 (Pardé, 1937) are well simulated.
Temperature reconstructions from Fig. 6 are compared between the different datasets on annual and seasonal timescales. The interannual variability is quite satisfactorily simulated, but the uncertainty in the reconstructions seems underestimated, with observations being too often out of the range of SCOPE Climate members. Summer temperatures 
are generally underestimated, whereas winter temperatures are generally overestimated, leading to a systematic underor overestimation of temperature in hot or cold years. However, the recent trend in spring and summer temperature is captured - although underestimated - by the reconstruction method.

Some hot seasons are well captured, such as the 19421948 period for spring, and especially the hot spring of 1945 (Martin, 1946) or the more recent hot summer of 1976 (Brochet, 1977). The cold autumn of 1912 is also well captured by SCOPE Climate (Puiseux, 1913, p. 63). Temperature for other events like the extremely cold winter 19621963 (Geneslay, 1964) or the recent hot summer of 2003 (Trigo et al., 2005) are, however, over- or underestimated (about $+2{ }^{\circ} \mathrm{C}$ for 1963 and $-2.3{ }^{\circ} \mathrm{C}$ for 2003 in comparison to Safran), but still captured.

\subsection{Performance of SCOPE Climate against reference datasets}

The performance of SCOPE Climate is assessed using Safran as reference dataset. First, direct comparisons to Safran are made through the use of interannual regimes and visualization of time series at a daily time step in a specific year. Then, different skill scores are used to complete the validation of SCOPE Climate.

\subsubsection{Performance against the Safran reanalysis}

The interannual regimes from Safran and SCOPE Climate precipitation, temperature, and reference evapotranspiration are compared to each other on four different case study cells, belonging to four regions with very different climatic influences (Fig. 7). Precipitation regimes are well reconstructed by SCOPE Climate. Spring precipitation is slightly overestimated, whereas autumnal precipitation can be slightly underestimated (for Finistère and Corrèze). These results show that the SCOPE method is able to reproduce strong seasonal cycles (asymmetry between spring and autumn) as well as continental regimes. For temperature, the Safran regime is always inside the thin range of SCOPE Climate regimes in spring and autumn for all cells. Temperatures are slightly overestimated in winter and underestimated in summer. The regimes of reference evapotranspiration show differences between Safran and SCOPE Climate. For all cells, evapotranspiration is underestimated in spring and summer and overestimated in autumn and winter. Moreover, for the Finistère, SCOPE Climate maximum evapotranspiration is not seen in July, as for Safran, but in August, leading to a shifted seasonal cycle. This shows the importance of variables other than temperature in the computation of reference evapotranspiration and a lack of information on these variables in SCOPE predictors.

The year 2011 has been chosen as an example to show SCOPE Climate and Safran at a daily time step. This year remains outside of the Safran archive period used to create SCOPE Climate (1958-2008) and is among the hottest years since $1900^{2}$. Precipitation, temperature, and evapotranspiration time series from both Safran and SCOPE Climate are presented in Fig. 8 for the Finistère grid cell (see Fig. 7). Safran precipitation is included most of the time in the range of the 25 reconstructions, except for extremely wet days above $20 \mathrm{~mm}$. There are only a few days on which both Safran and all 25 members reconstruct zero precipitation. Nevertheless, the sequence of alternating dry and wet periods is well respected in SCOPE Climate. Member 1 provides a good reconstruction of Safran precipitation with a slight overestimation for moderate episodes and an underestimation for strong episodes. Safran temperature is almost always included in the - sometimes very thin - range of SCOPE Climate temperatures, showing the small bias of the SCOPE method. The overall Safran variability is well reconstructed by Member 1 of SCOPE Climate. The good results obtained for precipitation and temperature do not apply to evapotranspiration. Indeed, even if Safran evapotranspiration is included in the extremely large range of SCOPE Climate reconstructions, the day-to-day variability reconstructed by Member 1 is far too high in comparison to Safran, especially in winter. Moreover, the sign of these day-to-day variations (increase or decrease) is sometimes not the same for Safran and Member 1 of SCOPE Climate. In spite of a good reconstruction of precipitation and temperature, evapotranspiration results lack autocorrelation. Caution is therefore required if SCOPE Climate is used for studying specific events for which evapotranspiration plays an important role, such as the 2003 drought (Teuling et al., 2013).

Figure 9 shows the median of annual and seasonal precipitation, temperature and reference evapotranspiration bias between Safran and SCOPE Climate over the 1959-2007 period (complete years in the archive period). The median of annual precipitation bias between Safran and SCOPE Climate shows an absolute value under $5 \%$ for the whole of France, except for a specific area in the Cévennes region (top row of Fig. 9). In summer, autumn, and winter, the bias is generally under $5 \%$ in absolute value and up to $\pm 15 \%$ for specific areas. Spring precipitation is overestimated for the Atlantic coast and the Mediterranean region. As spring is the only season showing an overestimation of precipitation after the second step of the SCOPE method (see Sect. 2.2.2), removing dry days for this season as done in Sect. 2.2.3 will exacerbate the precipitation overestimation. This could be managed by adapting the number of dry days to be removed depending on the season, as it is done for the zones. Nevertheless, for the sake of parsimony and because the bias correction is already adapted to each zone, the choice was made to have the same parameters for all seasons. The median of

\footnotetext{
${ }^{2} \mathrm{http}: / / \mathrm{www} \cdot m e t e o f r a n c e . f r / c l i m a t-p a s s e-e t-f u t u r /$ bilans-climatiques/autres-annees/bilan-de-lannee-2011 access: 20 February 2018).
}

(last 


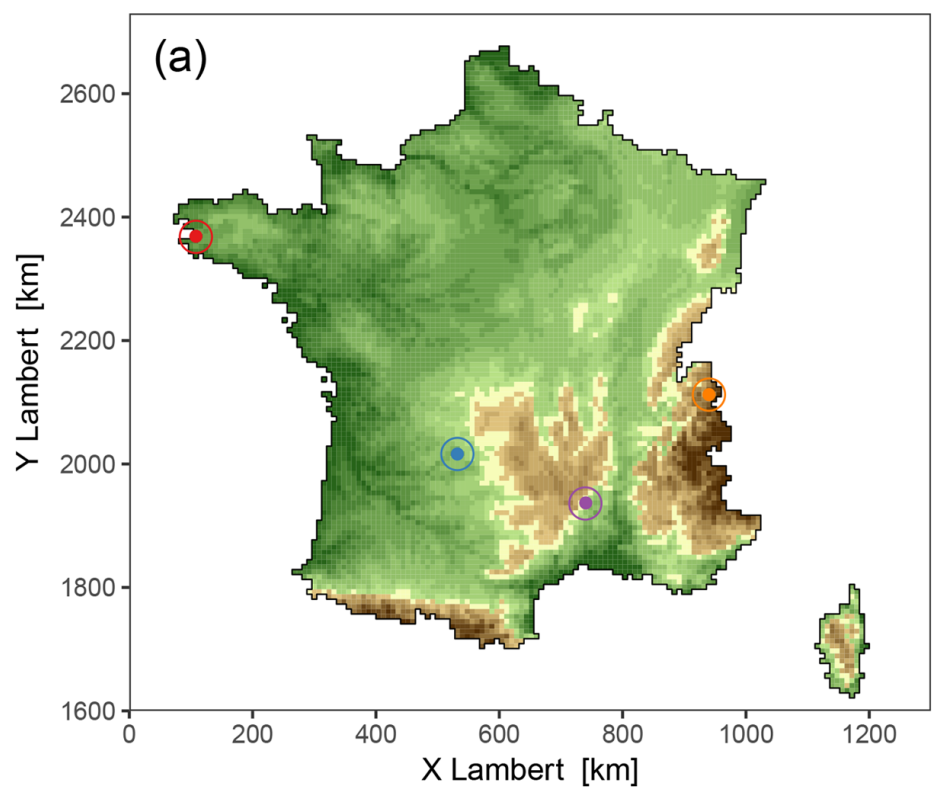

Cells

- Finistère

- Haute Savoie

- Corrèze

- Cévennes

(b)
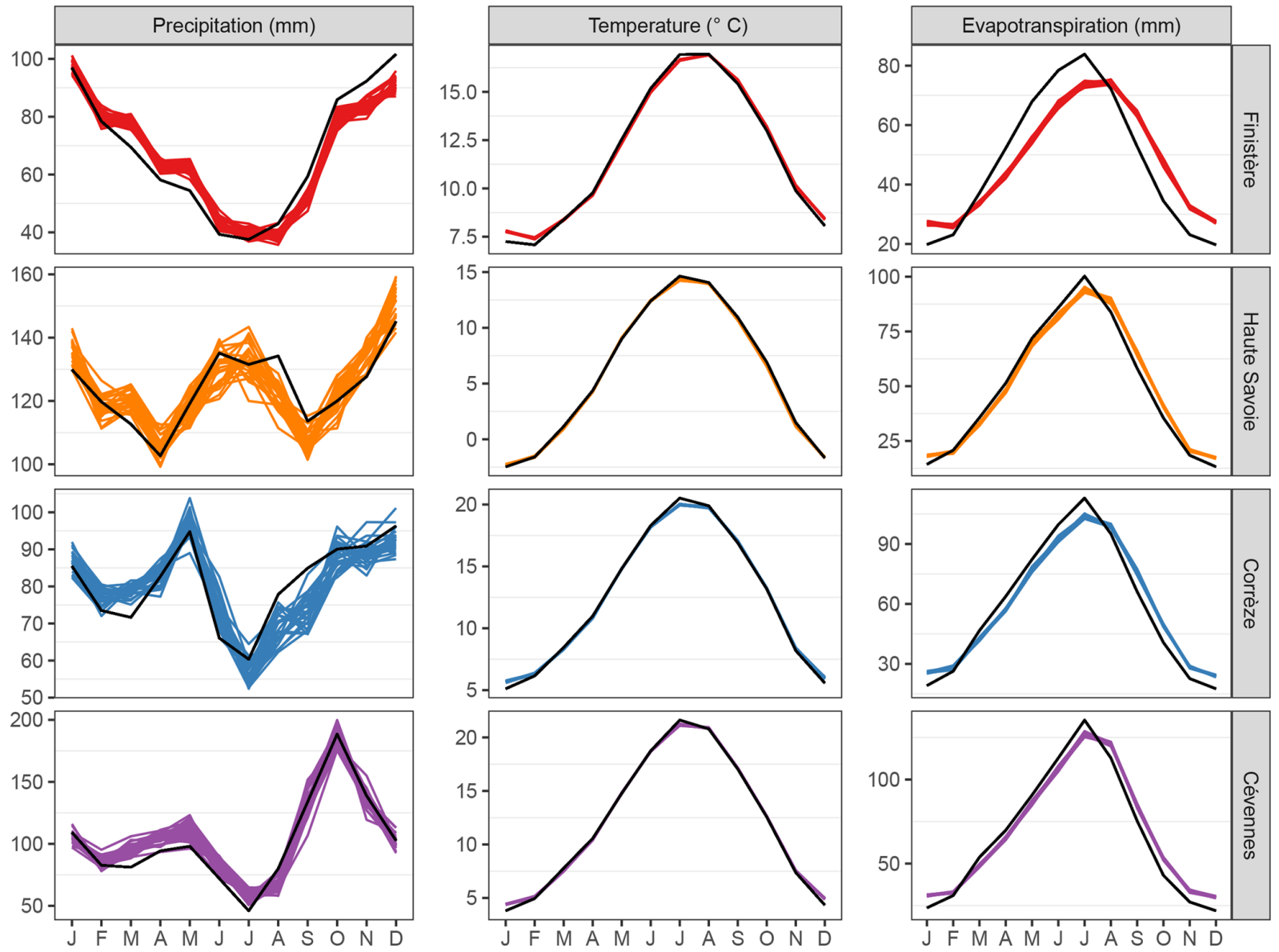

Figure 7. (a) Topographical map of France with location of the 4 case study cells: Finistère in Brittany, Haute-Savoie in the French Alps, Corrèze in the south-west, and Cévennes in the Massif Central mountain range. Brown corresponds to altitudes above $650 \mathrm{~m}$ (up to $2933 \mathrm{~m}$ ). Green corresponds to altitudes under $500 \mathrm{~m}$. (b) Precipitation, temperature, and reference evapotranspiration interannual regimes between 1959 and 2007 from Safran (black) and SCOPE Climate (colours), through the 25 individual members, for the case study cells. 

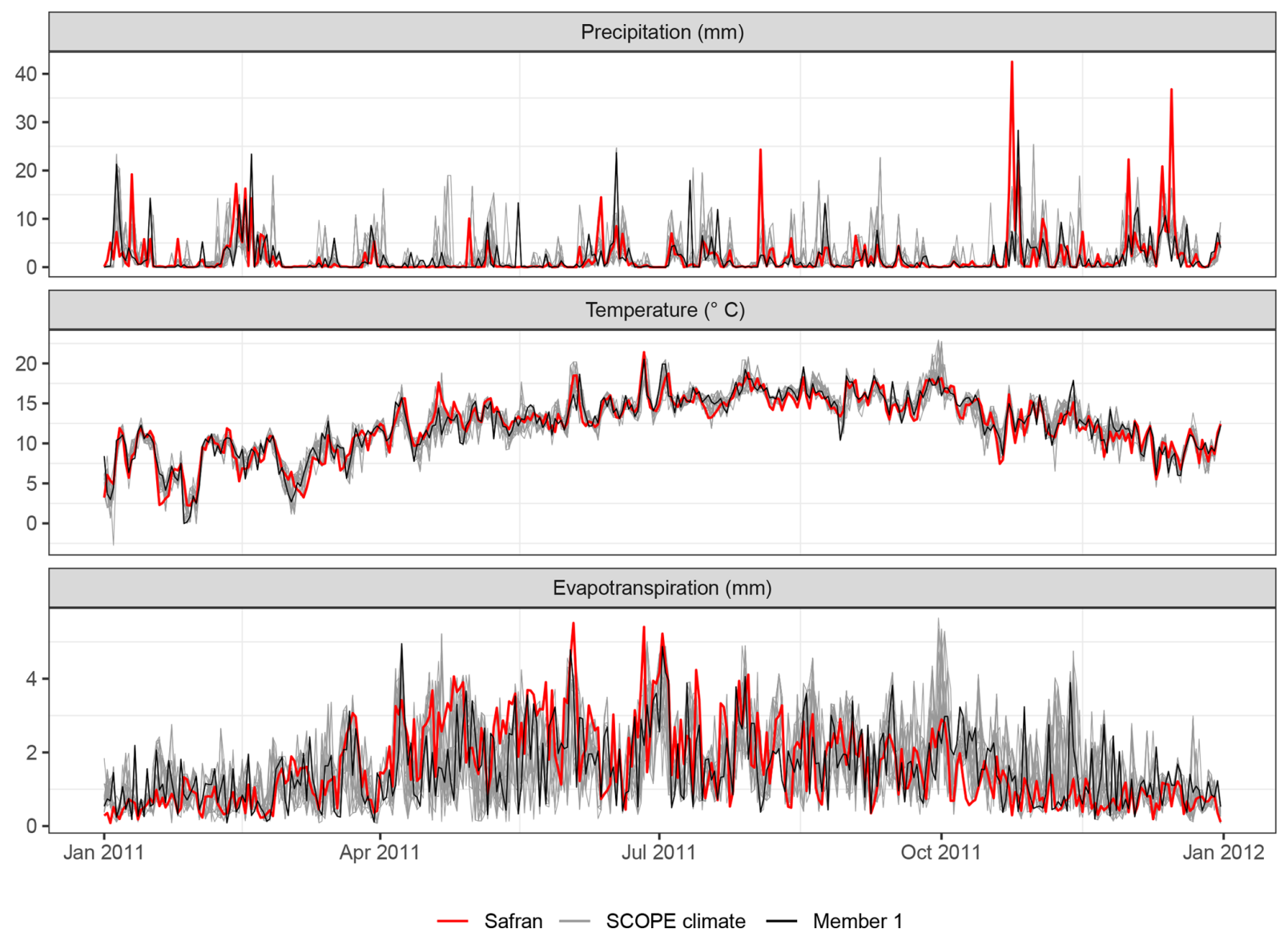

Figure 8. Precipitation, temperature, and reference evapotranspiration reconstructed series from SCOPE Climate compared to Safran in 2011 at a daily time step for the Finistère grid cell (see Fig. 7). Light grey time series correspond to the 25 members of SCOPE Climate, Member 1 is plotted in black for exemplifying autocorrelation in individual member time series.

annual and seasonal temperature bias is low (middle row of Fig. 9). It is limited to $\pm 0.20^{\circ} \mathrm{C}$ on the annual scale and generally stays under $\pm 0.60{ }^{\circ} \mathrm{C}$ on the seasonal scale. The maximum bias is reached for a small region in the north-west of France and around Paris with an overestimation of $+0.63{ }^{\circ} \mathrm{C}$ in winter. The median evapotranspiration bias is kept under $\pm 10 \%$ on the annual timescale, and largely under $\pm 20 \%$ in spring and summer. This bias is higher in autumn and especially in winter, with an overestimation of evapotranspiration between $30 \%$ and $40 \%$ for the north-east of France (up to $50 \%$ for Brittany). The SCOPE method has not been adapted for reference evapotranspiration specifically, and the results obtained for this variable should therefore be taken with care. Evapotranspiration biases are due to a larger selection of analogue days in other seasons than the target day season. This feature, strongly present in SANDHY outputs, has been reduced with the addition of the stepwise subselection (see Sect. 2.2.2). Nevertheless, this is not enough to remove the biases in reference evapotranspiration.

The median of annual correlations between Safran precipitation and SCOPE Climate precipitation over the 1959-2007 period shows values above 0.6 except for the south-east of France (Fig. 10). Correlations are similar for the spring season, but are lower for summer. This can be explained by the numerous local storms occurring in summer, which are hardly predictable by the SCOPE method. Precipitation correlations are generally above 0.8 in autumn and winter. The median of correlations for temperature shows values generally above $0.8-0.9$ for the annual and seasonal time steps, with only a few zones in autumn showing lower values. For reference evapotranspiration, the median correlations are generally above 0.6 for all time steps, except for winter when a large part of France shows low correlations. This last result is consistent with results from Fig. 8.

The continuous ranked probability score (CRPS, Brown, 1974; Matheson and Winkler, 1976) is used to compute a probabilistic evaluation of SCOPE Climate at daily, monthly, and annual time steps. This score is equivalent to the mean absolute error in a deterministic context. After normalization by a climatological reference, the continuous ranked probability skill score (CRPSS; see Sect. 3.4 in Caillouet et al., 2016 , for more details) allows for a comparison of zones with 

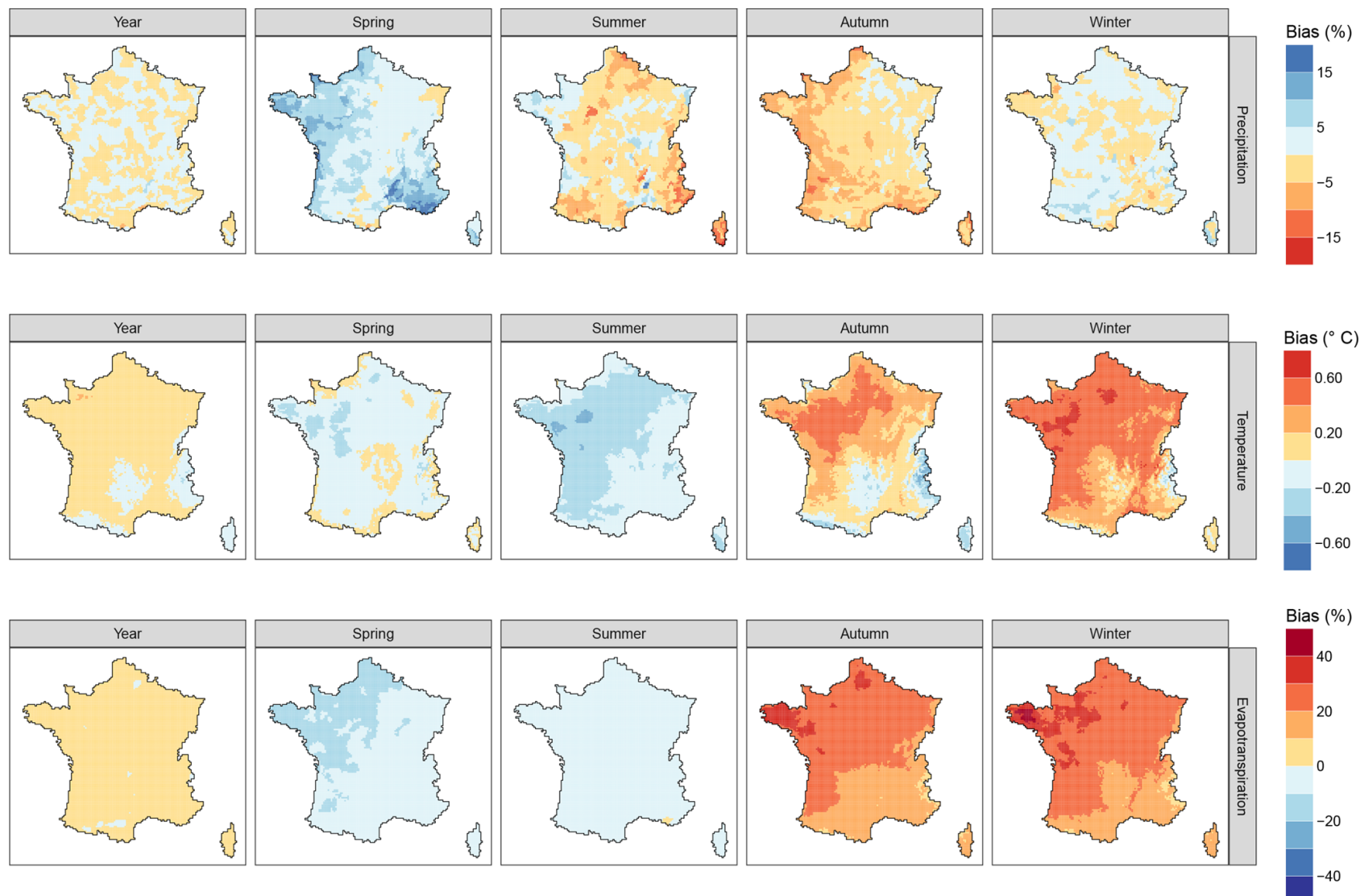

Figure 9. Median of annual and seasonal precipitation (top row), temperature (middle row), and evapotranspiration (bottom row) bias between Safran and SCOPE Climate for the 1959-2007 period. Red corresponds to an overestimation of the reconstructed temperature and reference evapotranspiration as well as an underestimation of the reconstructed precipitation.

different climates. Here, the climatology is calculated using data from Safran over the archive period (1958-2008), taking seasonality into account. The CRPSS is shown in Fig. 11 for all variables of SCOPE Climate and all time steps. Positive CRPSS values denote an improved skill with respect to the climatology, and 1 reflects a perfect reconstruction. For precipitation, the spatial distribution of the CRPSS is similar for the three time steps. The lowest performances are found for the Mediterranean coast, the east of France, Corsica, and the eastern part of Massif Central. The highest CRPSS values are found for the Atlantic coast, the French Alps, the Cévennes area, and the western parts of the Massif Central, Jura, and Vosges mountain ranges. For temperature, the highest scores for the daily and monthly time steps are obtained for mountainous areas, while the lowest ones are obtained for the north-west (only for the monthly time step), south-east, and Corsica. A much smoother spatial distribution is found at the daily and monthly time steps compared to the annual time step. At the annual time step, the highest scores are obtained for the north-west of France, and some specific cells in the south-east have a negative CRPSS. For reference evapotranspiration, the spatial distribution of CRPSS is similar at the daily and monthly time steps: the highest scores are found for the south-east of France, and particularly for the French Alps and the western part of Massif Central. The lowest scores are found for the north-west of France, and the major part of France shows negative values at the monthly time step. This negative skill is partly explained by the shifted seasonal cycle (see Fig. 7) in addition to the seasonal bias (see Fig. 9). As for temperature, the spatial distribution of CRPSS at the annual time step shows relatively high spatial discontinuities. Most of France shows positive annual values, except for Corsica, where strong negative values are found.

\subsection{Performance against homogenized times series}

The evolution of the spatially averaged root mean square error (RMSE) for both Safran and SCOPE Climate is presented in Fig. 12 using the homogenized series as a reference. Monthly RMSEs are first calculated using the 323 precipitation time series and the 65 temperature time series. This leads to one value of RMSE per month for Safran and 25 values of RMSE per month for SCOPE Climate. These RMSEs are then averaged yearly for each SCOPE Climate member. The RMSE in $\mathrm{mm} \mathrm{yr}^{-1}$ is then divided by the number of days in 

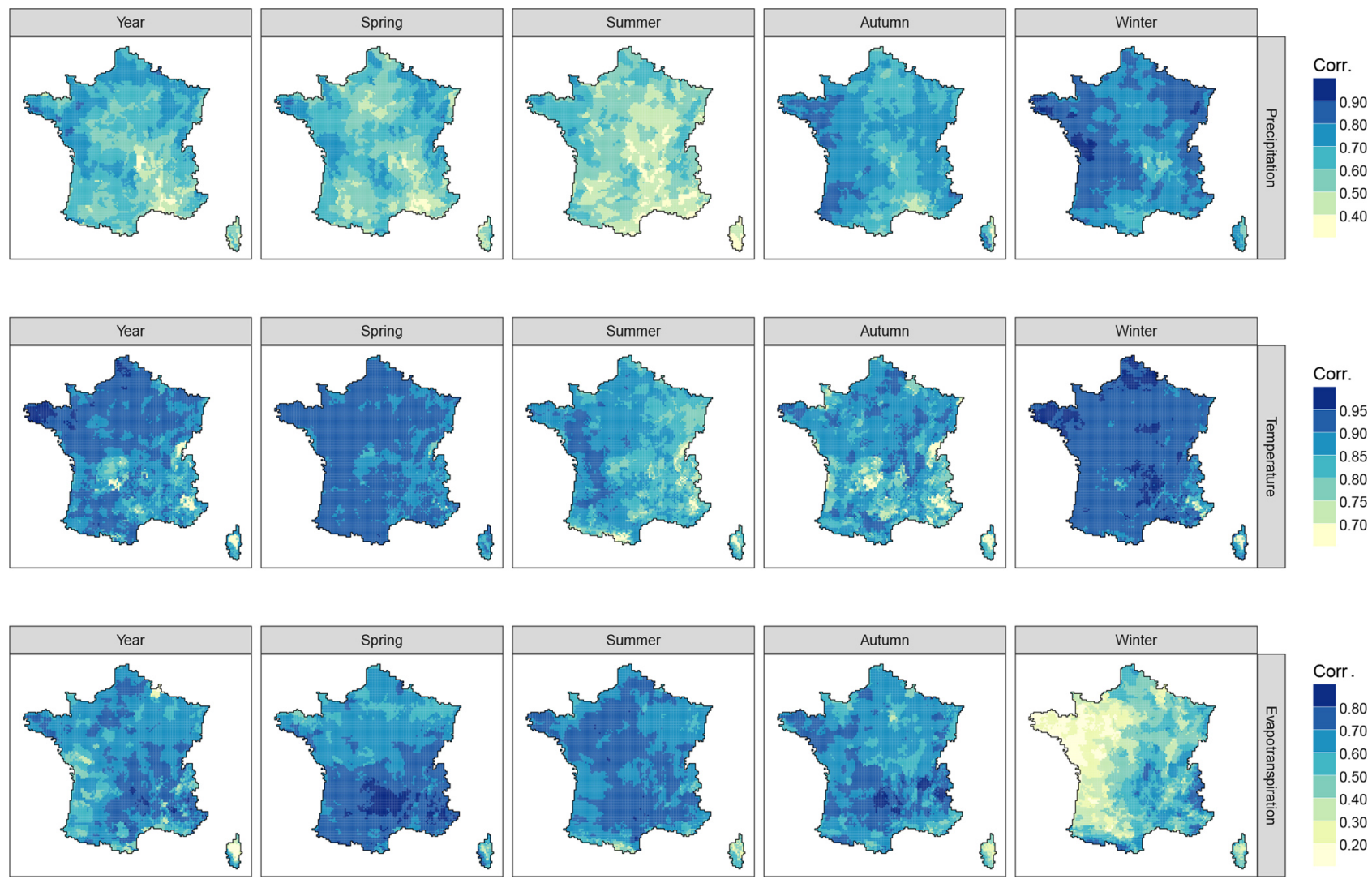

Figure 10. Median of annual and seasonal precipitation (top row), temperature (middle row), and reference evapotranspiration (bottom row) correlation between Safran and SCOPE Climate for the 1959-2007 period.

each year to get an RMSE in mm day ${ }^{-1}$. Coloured intervals then show the range between minimum and maximum annual values of the 25 members. For precipitation, RMSEs are relatively constant over time, with an average value around $1.3 \mathrm{~mm} \mathrm{day}^{-1}$. They are, however, slightly higher before the 1940s. It is important to note that Safran errors, which were documented by Vidal et al. (2010), account for nearly half (around $0.6 \mathrm{~mm} \mathrm{day}^{-1}$ ) of the reconstruction errors. For temperature, SCOPE Climate RMSEs are around $1{ }^{\circ} \mathrm{C}$ over the entire period. It even reaches down to $0.9^{\circ} \mathrm{C}$ over $1959-2000$ when Safran errors are around $0.8^{\circ} \mathrm{C}$.

\section{Data availability}

SCOPE Climate is a 142-year high-resolution ensemble gridded daily meteorological reconstruction of precipitation, temperature and reference evapotranspiration over France. This dataset is the result of the statistical downscaling of 20CR by the SCOPE method. Results are available for 25 members at a daily time step and over a $8 \mathrm{~km}$ grid. This dataset is spatially coherent over France and has a high intervariable coherence, thus enabling studies requiring spatial and multi-variable meteorological variables, such as hydrological studies. SCOPE Climate has been used as forcings to create the SCOPE Hydro dataset that provides ensemble daily streamflow time series for more than 600 near-natural catchments in France over the 1871-2012 period (Caillouet et al., 2017). It has also been used to study spatio-temporal extreme low-flow events in France since 1871 by Caillouet et al. (2017).

The SCOPE Climate dataset is available under the Attribution-NonCommercial 4.0 International (CC BY-NC 4.0): One may copy and redistribute the material in any medium or format, remix, transform and build upon the material with the following terms: (1) Attribution - one must give appropriate credit, provide a link to the license, and indicate whether changes were made. One may do so in any reasonable manner, but not in any way that suggests the licensor endorses you or your use. (2) NonCommercial - one may not use the material for commercial purposes.

SCOPE Climate is available through the Zenodo repository (http://zenodo.org, last access: 14 February 2019), as three different datasets, with one for each variable (precipitation, temperature, and reference evapotranspiration). Each dataset stores $25 \mathrm{NetCDF}$ files corresponding to the 25 SCOPE Climate members. Please note that when using multiple variables simultaneously, e.g. precipitation and temperature, one may use precipitation from member 1 with tem- 

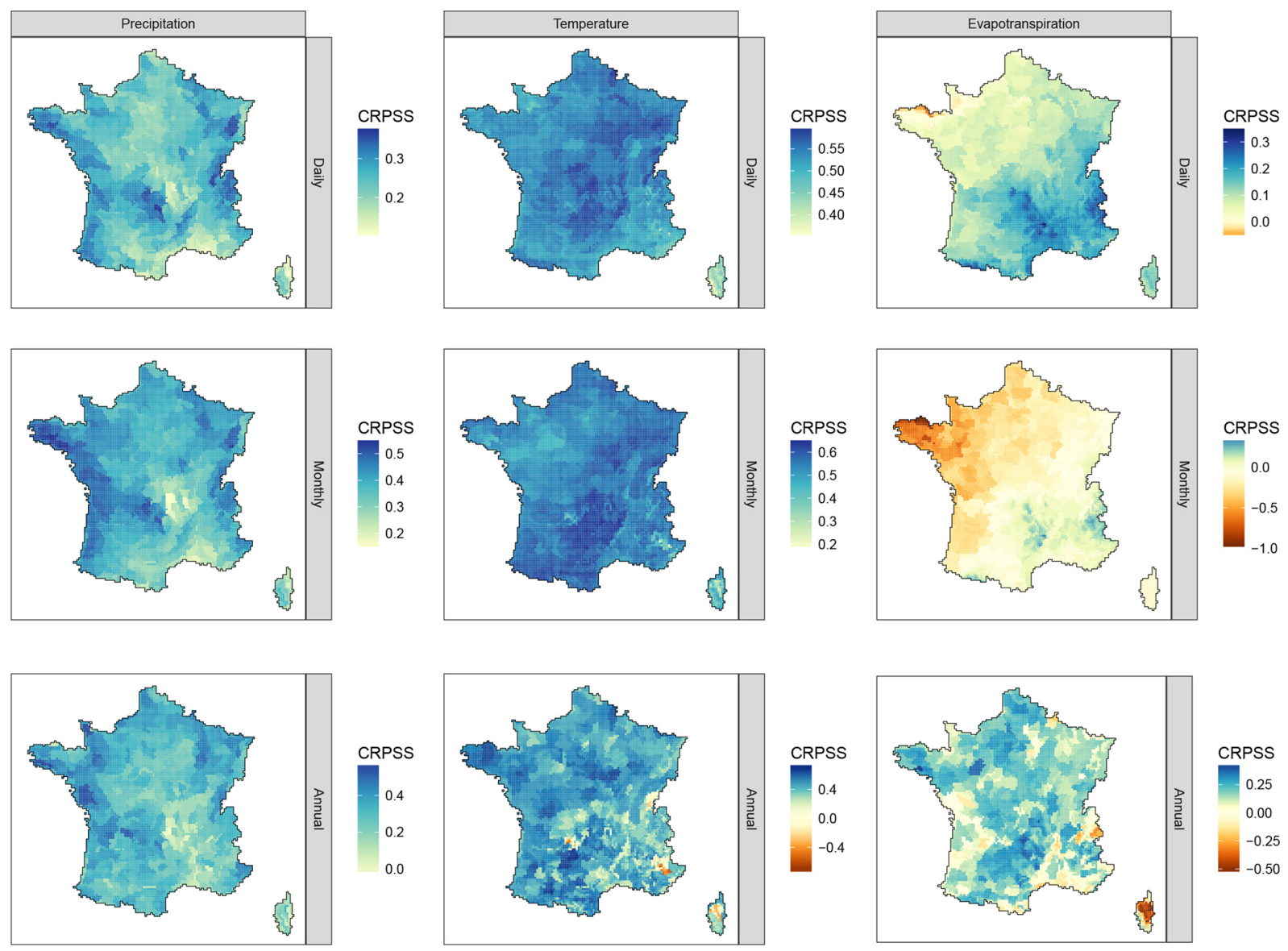

Figure 11. Daily, monthly, and annual CRPSS between SCOPE Climate and Safran for precipitation, temperature, and reference evapotranspiration over the 1959-2007 period. Note the different scales across the maps.

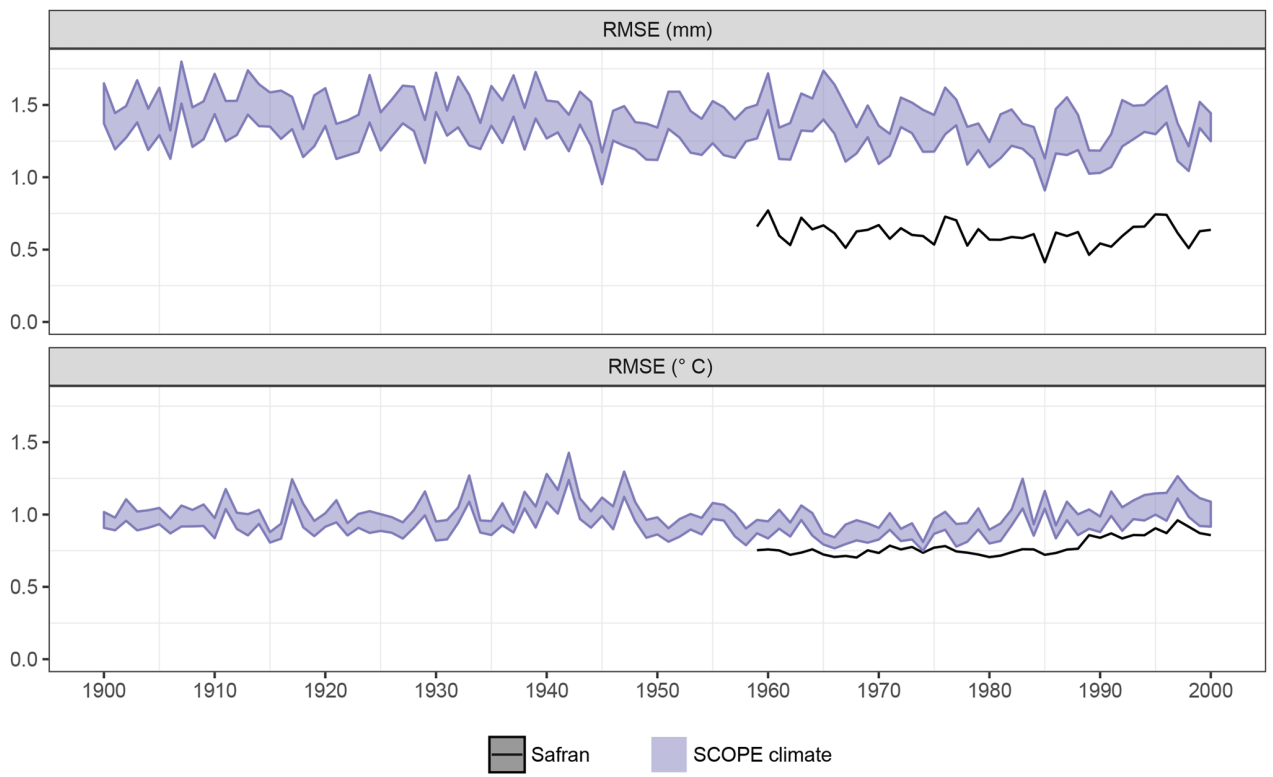

Figure 12. Temporal evolution of the precipitation and temperature RMSE for both Safran and SCOPE Climate, with the homogenized series as a reference. Values are initially computed on the monthly timescale. See text for details. 
perature from member 1 (and member 2 with member 2 ), as SCOPE Climate provides consistent gridded values across variables for any single member. SCOPE Climate can be downloaded as NetCDF files for precipitation (Caillouet et al., 2018a), temperature (Caillouet et al., 2018b), and reference evapotranspiration (Caillouet et al., 2018c).

\section{Conclusions}

The use of SCOPE Climate is conditional on the large-scale information provided by the 20CR atmospheric reanalysis, and using an alternative extended reanalysis like ERA-20C may lead to different outputs (see Dayon et al., 2015; Horton and Brönnimann, 2018). SCOPE Climate takes into account the uncertainty related to the SCOPE method, but not the uncertainty related to 20CR, as only the ensemble mean has been considered. As discussed by Caillouet et al. (2016), the different members of 20CR show an increased spread before the 1930s-1940s, because of too few data assimilated during this period. SCOPE Climate might thus show a lower quality before this period. Similarly, using another statistical downscaling method from either 20CR or ERA20C may lead to different outputs (see e.g. Horton and Brönnimann, 2018).

Results for reference evapotranspiration showed weak performances at daily and monthly time steps. This issue could be fixed by having some kind of calendar selection in the downscaling process. Ben Daoud et al. (2011), however, showed that the performance in estimating precipitation is lower when replacing the first analogy level in SANDHY with a calendar preselection. Caillouet et al. (2016) additionally showed that having a stepwise subselection of SANDHY outputs led to higher rank correlations and lower mean errors between observed and reconstructed temperatures than a calendar subselection. Moreover, setting fixed seasons would not be necessarily suitable for our case - a long-term historical reconstruction - as there could be season shifts. Thus, it is not recommended to use SCOPE Climate for studies specifically on evapotranspiration. Nevertheless, it is possible to use this variable in hydrological modelling for regions and/or temporal periods where/when this variable is not the main driver of streamflow. Caillouet et al. (2017) showed that streamflow reconstructions driven by SCOPE Climate have a high skill for most of the 662 near-natural catchments considered across France.

Time series were constructed in SCOPE Climate by independently combining analogue dates from one day to another and the only temporal coherence is ensured by that of the large-scale predictors. The Schaake Shuffle allows, in a forecasting context, for a temporal coherence to be retrieved over the forecast horizon, on top of the spatial and inter-variable coherence. Such a desirable property is, however, hampered here by the length over which temporal coherence is required (142 years), which is larger than the archive period (50 years) from which this empirical coherence can be extracted.
Convective precipitation events usually stem from very local processes and are therefore hardly detectable from only large-scale information. This is why downscaling methods have some difficulty in reconstructing such events, and SANDHY (and thus SCOPE) is no exception. For this reason, SCOPE Climate should not be used to study specifically convective events.

Finally, as the downscaling method is based on the analogue principle, it is not possible to reconstruct higher (for precipitation, temperature and reference evapotranspiration) or lower (for temperature) values than the ones available in the archive dataset. Nevertheless, values averaged over several days or over several climatically homogeneous zones may exceed these limits. The performance of SCOPE Climate in reconstructing convective precipitation events has not been assessed and may be lower than for stratiform events as relevant information may not be included in large-scale predictors of the SCOPE method.

Author contributions. LC developed the dataset and prepared the manuscript. JPV, ES, and BG contributed to the development of the dataset. JMS supplied the Safran reanalysis. All co-authors contributed to the manuscript.

Competing interests. The authors declare that they have no conflict of interest.

Acknowledgements. Support for the Twentieth Century Reanalysis Project dataset is provided by the U.S. Department of Energy, Office of Science Innovative and Novel Computational Impact on Theory and Experiment (DOE INCITE) programme, and Office of Biological and Environmental Research (BER), and by the National Oceanic and Atmospheric Administration Climate Program Office. The authors would like to thank Météo-France for providing access to the Safran database. Analyses were performed in R ( R Core Team, 2016), with packages dplyr (Wickham and Francois, 2015), ggplot2 (Wickham, 2009), RColorBrewer (Neuwirth, 2014), reshape2 (Wickham, 2007), sp (Pebesma and Bivand, 2005; Bivand et al., 2013), grid (R Core Team, 2016), gridExtra (Auguie, 2016), and scales (Wickham, 2016). Laurie Caillouet's PhD thesis was funded by Irstea and CNR.

Edited by: David Carlson

Reviewed by: two anonymous referees

\section{References}

Allen, R. G., Pereira, L. S., Raes, D., and Smith, M.: Crop Evapotranspiration - Guidelines for computing crop water requirements, FAO Irrigation and Drainage Paper 56, FAO, Rome, 1998

Auguie, B.: gridExtra: Miscellaneous Functions for "Grid" Graphics, available at: https://CRAN.R-project.org/package=gridExtra (last access: 14 February 2019), R package version 2.2.1, 2016. 
Ben Daoud, A., Sauquet, E., Lang, M., Bontron, G., and Obled, C.: Precipitation forecasting through an analog sorting technique: a comparative study, Adv. Geosci., 29, 103-107, https://doi.org/10.5194/adgeo-29-103-2011, 2011.

Ben Daoud, A., Sauquet, E., Bontron, G., Obled, C., and Lang, M.: Daily quantitative precipitation forecasts based on the analogue method: Improvements and application to a French large river basin, Atmos. Res., 169, 147-159, https://doi.org/10.1016/j.atmosres.2015.09.015, 2016.

Bivand, R. S., Pebesma, E., and Gomez-Rubio, V.: Applied spatial data analysis with R, Second edition, Springer, NY, available at: http://www.asdar-book.org/ (last access: 14 February 2019), 2013.

Blanchet, G.: Le temps dans la région RhóneAlpes en 1983, Géocarrefour, 59, 347-365, https://doi.org/10.3406/geoca.1984.4041, 1984.

Bonnet, R., Boé, J., Dayon, G., and Martin, E.: Twentieth-century hydrometeorological reconstructions to study the multidecadal variations of the water cycle over France, Water Resour. Res., 53, 8366-8382, https://doi.org/10.1002/2017WR020596, 2017.

Boudou, M., Danière, B., and Lang, M.: Assessing changes in urban flood vulnerability through mapping land use from historical information, Hydrol. Earth Syst. Sci., 20, 161-173, https://doi.org/10.5194/hess-20-161-2016, 2016.

Brochet, P.: La sécheresse 1976 en France: aspects climatologiques et conséquences, Hydrol. Sci. B., 22, 393-411, https://doi.org/10.1080/02626667709491733, 1977.

Brown, T. A.: Admissible scoring systems for continuous distributions, Tech. rep., The Rand Corporation, Santa Monica, CA, 1974.

Caillouet, L., Vidal, J.-P., Sauquet, E., and Graff, B.: Probabilistic precipitation and temperature downscaling of the Twentieth Century Reanalysis over France, Clim. Past, 12, 635-662, https://doi.org/10.5194/cp-12-635-2016, 2016.

Caillouet, L., Vidal, J.-P., Sauquet, E., Devers, A., and Graff, B.: Ensemble reconstruction of spatio-temporal extreme low-flow events in France since 1871, Hydrol. Earth Syst. Sc., 21, 29232951, https://doi.org/10.5194/hess-21-2923-2017, 2017.

Caillouet, L., Vidal, J.-P., Sauquet, E., Graff, B., and Soubeyroux, J.-M.: SCOPE Climate: precipitation (Version v1.0.0), [Data set], Zenodo, https://doi.org/10.5281/zenodo.1299760, 2018a.

Caillouet, L., Vidal, J.-P., Sauquet, E., Graff, B., and Soubeyroux, J.-M.: SCOPE Climate: temperature (Version v1.0.0), [Data set], Zenodo, https://doi.org/10.5281/zenodo.1299712, 2018b.

Caillouet, L., Vidal, J.-P., Sauquet, E., Graff, B., and Soubeyroux, J.-M.: SCOPE Climate: Penman-Monteith reference evapotranspiration (Version v1.0.0), [Data set], Zenodo, https://doi.org/10.5281/zenodo.1251843, 2018c.

Clark, M., Gangopadhyay, S., Hay, L., Rajagopalan, B., and Wilby, R.: The Schaake Shuffle: A Method for reconstructing space-Time variability in forecasted precipitation and temperature fields, J. Hydrometeorol., 5, 243-262, https://doi.org/10.1175/15257541(2004)005<0243:TSSAMF>2.0.CO;2, 2004.

Compo, G. P., Whitaker, J. S., Sardeshmukh, P. D., Matsui, N., Allan, R. J., Yin, X., Gleason, B. E., Vose, R. S., Rutledge, G., Bessemoulin, P., Bronnimann, S., Brunet, M., Crouthamel, R. I., Grant, A. N., Groisman, P. Y., Jones, P. D., Kruk, M. C., Kruger, A. C., Marshall, G. J., Maugeri, M., Mok, H. Y., Nordli, O., Ross,
T. F., Trigo, R. M., Wang, X. L., Woodruff, S. D., and Worley, S. J.: International Surface Pressure Databank (ISPDv2), 2010.

Compo, G. P., Whitaker, J. S., Sardeshmukh, P. D., Matsui, N., Allan, R. J., Yin, X., Gleason, B. E., Vose, R. S., Rutledge, G., Bessemoulin, P., Brönnimann, S., Brunet, M., Crouthamel, R. I., Grant, A. N., Groisman, P. Y., Jones, P. D., Kruk, M. C., Kruger, A. C., Marshall, G. J., Maugeri, M., Mok, H. Y., Nordli, Ø., Ross, T. F., Trigo, R. M., Wang, X. L., Woodruff, S. D., and Worley, S. J.: The Twentieth Century Reanalysis Project, Q. J. Roy. Meteor. Soc., 137, 1-28, https://doi.org/10.1002/qj.776, 2011.

Dayon, G., Boé, J., and Martin, E.: Transferability in the future climate of a statistical downscaling method for precipitation in France, J. Geophys. Res., 120, 1023-1043, https://doi.org/10.1002/2014JD022236, 2015.

Delserieys, M. and Blanchard, R.: District Seine-Normandie, in: Les inondations remarquables en France, edited by: Lang, M. and Cœur, D., chap. 6, 381-456, Quæ, Versailles, France, 2014.

Duband, D., Schoeneich, P., and Stanescu, V. A.: The example of 1921 drought in Europe (Italy, France, Romania, Switzerland...): climatology and hydrology, Houille Blanche, 18-29, https://doi.org/10.1051/lhb:200405001, 2004.

Gautier, J.-N., Mergenthaler, S., and Camp'Huis, N.-G.: La crue d'octobre 1872 en France (Loire), en Italie (Po) et en Espagne (Ebre), Houille Blanche, 56-63, https://doi.org/10.1051/lhb:200405007, 2004.

Geneslay, E.: L'hiver 1962-1963, L'Astronomie, 78, 110-111, available at: http://adsabs.harvard.edu/full/1964LAstr..78..110G (last access: 14 February 2019), 1964.

Horton, P. and Brönnimann, S.: Impact of global atmospheric reanalyses on statistical precipitation downscaling, Clim. Dynam., https://doi.org/10.1007/s00382-018-4442-6, 2018.

Jourdain, S., Roucaute, E., Dandin, P., Javelle, J.-P., Donet, I., Ménassère, S., and Cénac, N.: Le sauvetage de données climatologiques anciennes à Météo-France: De la conservation des documents à la mise à disposition des données, La Météorologie, 47-55, https://doi.org/10.4267/2042/56598, 2015.

Keller, V. D. J., Tanguy, M., Prosdocimi, I., Terry, J. A., Hitt, O., Cole, S. J., Fry, M., Morris, D. G., and Dixon, H.: CEH-GEAR: $1 \mathrm{~km}$ resolution daily and monthly areal rainfall estimates for the UK for hydrological and other applications, Earth Syst. Sci. Data, 7, 143-155, https://doi.org/10.5194/essd-7-143-2015, 2015.

Kuentz, A., Mathevet, T., Gailhard, J., and Hingray, B.: Building long-term and high spatio-temporal resolution precipitation and air temperature reanalyses by mixing local observations and global atmospheric reanalyses: the ANATEM method, Hydrol. Earth Syst. Sc., 19, 2717-2736, https://doi.org/10.5194/hess-192717-2015, 2015.

Lang, M., Cœur, D., Bard, A., Bacq, B., Becker, T., Bignon, E., Blanchard, R., Bruckmann, L., Delserieys, M., Edelblutte, C., and Merle, C.: Les inondations remarquables en France : premiers éléments issus de l'enquête EPRI 2011, Houille Blanche, 37-47, https://doi.org/10.1051/lhb/2013041, 2013.

Lorenz, E. N.: Atmospheric predictability as revealed by naturally occurring analogues, J. Atmos. Sci., 26, 636-646, https://doi.org/10.1175/15200469(1969)26<636:APARBN>2.0.CO;2, 1969.

Marti, R. and Lepelletier, T.: L'hydrologie de la crue de 1910 et autres grandes crues du bassin de la Seine, Houille Blanche, 3339, https://doi.org/10.1051/lhb/1997074, 1997. 
Martin, B., Ansel, R., Guerrouah, O., Vitoux, M.-C., With, L., Drescher, A., Glaser, R., Himmelsbach, I., and Schönbein, J.: Géohistoire critique de la crue de janvier 1910 dans le Fossé Rhénan (Alsace/Pays de Bade), Houille Blanche, 62-68, https://doi.org/10.1051//hb/2011008, 2011.

Martin, H.: Apercu climatologique de la période 1940 à 1945, Ciel et Terre, 62, 37, available at: http://adsabs.harvard.edu/full/ 1946C\&T....62...37M (last access: 14 February 2019), 1946.

Matheson, J. E. and Winkler, R. L.: Scoring rules for continuous probability distributions, Manage Sci., 22, 1087-1096, 1976.

Minvielle, M., Pagé, C., Céron, J.-P., and Besson, F.: Extension of the SIM Reanalysis by combination of observations and statistical downscaling, in: Engineering Geology for Society and Territory, edited by: Lollino, G., Manconi, A., Clague, J., Shan, W., and Chiarle, M., Vol. 1, 189-192, Springer, https://doi.org/10.1007/978-3-319-09300-0_36, 2015.

Moisselin, J.-M. and Schneider, M.: Homogenization of French rainfall long term data series, Houille Blanche, 126-130, https://doi.org/10.1051//hb/2002096, 2002.

Moisselin, J.-M., Schneider, M., Canellas, C., and Mestre, O.: Les changements climatiques en France au XXème siecle, La Météorologie, 38, 45-56, https://doi.org/10.4267/2042/36233, 2002.

Neuwirth, E.: RColorBrewer: ColorBrewer Palettes, available at: https://CRAN.R-project.org/package=RColorBrewer (last access: 14 February 2019), R package version 1.1-2, 2014.

Nouailhac-Pioch, M. and Maillet, E.: Monographie de la crue de janvier-février-mars 1910, 1910.

Pardé, M.: Le régime du Rhóne, Rev. Geogr. Alp., 13, https://doi.org/10.3406/rga.1925.4941, 1925.

Pardé, M.: Enorme enneigement dans le haut bassin du Drac durant la saison froide 1935-1936, Rev. Geogr. Alp., 25, 421-422, https://doi.org/10.3406/rga.1937.4234, 1937.

Pardé, M.: Comments on the exceptional October 1960 flood in the western Central Massif, Houille Blanche, 695-698, https://doi.org/10.1051/lhb/1961012, 1961.

Pebesma, E. J. and Bivand, R. S.: Classes and methods for spatial data in R, R News, 5, 9-13, available at: http://CRAN.R-project. org/doc/Rnews/ (last access: 14 February 2019), 2005.

Poli, P., Hersbach, H., Dee, D. P., Berrisford, P., Simmons, A. J., Vitart, F., Laloyaux, P., Tan, D. G. H., Peubey, C., Thépaut, J.-N., Trémolet, Y., Hólm, E. V., Bonavita, M., Isaksen, L., and Fisher, M.: ERA-20C: An atmospheric reanalysis of the twentieth century, J. Climate, 29, 4083-4097, https://doi.org/10.1175/JCLI-D15-0556.1, 2016.

Puiseux, P.: Societe Astronomique de France séance du 7 Janvier 1913, L'Astronomie, 27, 54-64, available at: http://adsbit. harvard.edu//full/1913LAstr..27...54P/0000074.000.html (last access: 14 February 2019), 1913.

Quintana-Seguí, P., Le Moigne, P., Durand, Y., Martin, E., Habets, F., Baillon, M., Canellas, C., Franchistéguy, L., and Morel, S.: Analysis of near-surface atmospheric variables: validation of the safran analysis over france, J. Appl. Meteorol. Clim., 47, 92-107, https://doi.org/10.1175/2007JAMC1636.1, 2008.

Radanovics, S., Vidal, J.-P., Sauquet, E., Ben Daoud, A., and Bontron, G.: Optimising predictor domains for spatially coherent precipitation downscaling, Hydrol. Earth Syst. Sc., 17, 4189-4208, https://doi.org/10.5194/hess-17-4189-2013, 2013.
Rayner, N. A., Parker, D. E., Horton, E. B., Folland, C. K., Alexander, L. V., Rowell, D. P., Kent, E. C., and Kaplan, A.: Global analyses of sea surface temperature, sea ice, and night marine air temperature since the late nineteenth century, J. Geophys. Res., 108, 4407, https://doi.org/10.1029/2002JD002670, 2003.

R Core Team: R: A Language and Environment for Statistical Computing, R Foundation for Statistical Computing, Vienna, Austria, available at: https://www.R-project.org/ (last access: 14 February 2019), 2016.

Schneider, M.: Caractérisation météorologique de la crue de 1910, Houille Blanche, 28-32, https://doi.org/10.1051/lhb/1997073, 1997.

Sippel, S., Otto, F. E. L., Forkel, M., Allen, M. R., Guillod, B. P., Heimann, M., Reichstein, M., Seneviratne, S. I., Thonicke, K., and Mahecha, M. D.: A novel bias correction methodology for climate impact simulations, Earth Syst. Dynam., 7, 71-88, https://doi.org/10.5194/esd-7-71-2016, 2016.

Smith, T. M. and Reynolds, R. W.: Extended reconstruction of global sea surface temperatures based on COADS data (18541997), J. Climate, 16, 1495-1510, https://doi.org/10.1175/15200442-16.10.1495, 2003.

Smith, T. M., Reynolds, R. W., Peterson, T. C., and J., L.: Improvements to NOAA's historical merged land ocean surface temperature analysis (1880-2006), J. Climate, 21, 2283-2296, https://doi.org/10.1175/2007JCLI2100.1, 2008.

Tanguy, M., Prudhomme, C., Smith, K., and Hannaford, J.: Historical gridded reconstruction of potential evapotranspiration for the UK, Earth Syst. Sci. Data, 10, 951-968, https://doi.org/10.5194/essd-10-951-2018, 2018.

Teuling, A. J., Van Loon, A. F., Seneviratne, S. I., Lehner, I., Aubinet, M., Heinesch, B., Bernhofer, C., Grünwald, T., Prasse, H., and Spank, U.: Evapotranspiration amplifies European summer drought, Geophys. Res. Lett., 40, 2071-2075, https://doi.org/10.1002/grl.50495, 2013.

Teweles, J. and Wobus, H.: Verification of prognosis charts, B. Am. Meteorol. Soc., 35, 455-463, 1954.

Thibert, E., Eckert, N., and Vincent, C.: Climatic drivers of seasonal glacier mass balances: an analysis of 6 decades at Glacier de Sarennes (French Alps), The Cryosphere, 7, 47-66, https://doi.org/10.5194/tc-7-47-2013, 2013.

Trigo, R. M., García-Herrera, R., Díaz, J., Trigo, I. F., and Valente, M. A.: How exceptional was the early August 2003 heatwave in France?, Geophys. Res. Lett., 32, 1-4, https://doi.org/10.1029/2005GL022410, 2005.

Uppala, S. M., Kållberg, P. W., Simmons, A. J., Andrae, U., Da Costa Bechtold, V., Fiorino, M., Gibson, J. K., Haseler, J., Hernandez, A., Kelly, G. A., Li, X., Onogi, K., Saarinen, S., Sokka, N., Allan, R. P., Andersson, E., Arpe, K., Balmaseda, M. A., Beljaars, A. C. M., Van De Berg, L., Bidlot, J., Bormann, N., Caires, S., Chevallier, F., Dethof, A., Dragosavac, M., Fisher, M., Fuentes, M., Hagemann, S., Hólm, E., Hoskins, B. J., Isaksen, L., Janssen, P. A. E. M., Jenne, R., Mcnally, A. P., Mahfouf, J.-F., Morcrette, J.-J., Rayner, N. A., Saunders, R. W., Simon, P., Sterl, A., Trenberth, K. E., Untch, A., Vasiljevic, D., Viterbo, P., and Woollen, J.: The ERA-40 re-analysis, Q. J. Roy. Meteor. Soc., 131, 2961-3012, https://doi.org/10.1256/qj.04.176, 2005.

Vidal, J.-P., Martin, E., Franchistéguy, L., Baillon, M., and Soubeyroux, J.-M.: A 50-year high-resolution atmospheric reanalysis 
over France with the Safran system, Int. J. Clim., 30, 1627-1644, https://doi.org/10.1002/joc.2003, 2010.

Wickham, H.: Reshaping Data with the reshape Package, J. Stat. Softw., 21, 1-20, available at: http://www.jstatsoft.org/v21/i12/ (last access: 14 February 2019), 2007.

Wickham, H.: ggplot2: Elegant Graphics for Data Analysis, Springer-Verlag New York, available at: https://ggplot2. tidyverse.org/ (last access: 14 February 2019), 2009.
Wickham, H.: scales: Scale Functions for Visualization, available at: https://CRAN.R-project.org/package=scales (last access: 14 February 2019), R package version 0.4.0, 2016.

Wickham, H. and Francois, R.: dplyr: A Grammar of Data Manipulation, available at: https://CRAN.R-project.org/package=dplyr (last access: 14 February 2019), R package version 0.4.3, 2015. 